\title{
Identification of differentially expressed proteins in the injured lung from zinc chloride smoke inhalation based on proteomics analysis
}

Xiaowei $\mathrm{Xie}^{1+}$, Jingan Zhao ${ }^{1+}$, Lixin Xie ${ }^{1 *}$, Haiyan Wang ${ }^{2}$, Yan Xiao ${ }^{2}$, Yingjia She ${ }^{3}$ and Lingyun $\mathrm{Ma}^{2}$

\begin{abstract}
Background: Lung injury due to zinc chloride smoke inhalation is very common in military personnel and leads to a high incidence of pulmonary complications and mortality. The aim of this study was to uncover the underlying mechanisms of lung injury due to zinc chloride smoke inhalation using a rat model.

Methods: Histopathology analysis of rat lungs after zinc chloride smoke inhalation was performed by using haematoxylin and eosin (H\&E) and Mallory staining. A lung injury rat model of zinc chloride smoke inhalation (smoke inhalation for 1, 2, 7 and 14 days) was developed. First, isobaric tags for relative and absolute quantization (iTRAQ) and weighted gene co-expression network analysis (WGCNA) were used to identify important differentially expressed proteins. Gene Ontology (GO) and Kyoto Encyclopedia of Genes and Genomes (KEGG) pathway analyses were used to study the biological functions of differentially expressed proteins. Then, analysis of lung injury repairrelated differentially expressed proteins in the early (day 1 and day 2) and middle-late stages (day 7 and day 14) of lung injury after smoke inhalation was performed, followed by the protein-protein interaction (PPI) analysis of these differentially expressed proteins. Finally, the injury repair-related proteins PARK7 and FABP5 were validated by immunohistochemistry and western blot analysis.

Results: Morphological changes were observed in the lung tissues after zinc chloride smoke inhalation. A total of 27 common differentially expressed proteins were obtained on days 1, 2, 7 and 14 after smoke inhalation. WGCNA showed that the turquoise module (which involved 909 proteins) was most associated with smoke inhalation time. Myl3, Ckm, Adrm1 and lgfbp7 were identified in the early stages of lung injury repair. Gapdh, Acly, Tnni2, Acta1, Actn3, Pygm, Eno3 and Tpi1 (hub proteins in the PPI network) were identified in the middle-late stages of lung injury repair. Eno3 and Tpi1 were both involved in the glycolysis/gluconeogenesis signalling pathway. The expression of PARK7 and FABP5 was validated and was consistent with the proteomics analysis.
\end{abstract}

Conclusion: The identified hub proteins and their related signalling pathways may play crucial roles in lung injury repair due to zinc chloride smoke inhalation.

Keywords: Smoke inhalation, Lung injury, iTRAQ, WGCNA, Immunohistochemistry, Differentially expressed proteins, Signalling pathways

\footnotetext{
*Correspondence: laoxie301@126.com

${ }^{+}$Xiaowei Xie and Jingan Zhao contributed equally to this work and should

be considered as co-first authors.

'Medical School of Chinese PLA, Medical School of Chinese PLA, Fuxing

Road, Beijing 100853, China

Full list of author information is available at the end of the article
}

(c) The Author(s). 2019 Open Access This article is distributed under the terms of the Creative Commons Attribution 4.0 International License (http://creativecommons.org/licenses/by/4.0/), which permits unrestricted use, distribution, and reproduction in any medium, provided you give appropriate credit to the original author(s) and the source, provide a link to the Creative Commons license, and indicate if changes were made. The Creative Commons Public Domain Dedication waiver (http://creativecommons.org/publicdomain/zero/1.0/) applies to the data made available in this article, unless otherwise stated. 


\section{Introduction}

Military operations are complex and are always very dangerous because of toxic industrial chemicals and materials such as smoke bombs. Smoke bombs generate large amounts of particles and toxic gases during combustion and explosion. Therefore, lung smoke inhalation injuries are common in military personnel. It has been noted that smoke inhalation is the leading cause of lung injury [1]. In November 2014, 15 soldiers sustained lung injuries during smoke bomb inhalation [2, 3]. In addition, 3 soldiers sustained lung injuries during smoke bomb inhalation, and one of the soldiers died from the severe lung injury in January 2017 [4].

Generally, lung injury from smoke inhalation is defined as the inhalation of thermal or chemical irritants (such as zinc chloride), with a very high incidence of pulmonary complications and mortality [5-7]. A cough, difficulty breathing, nausea, vomiting and abnormal liver function are the main symptoms of lung injuries due to smoke inhalation. Despite many years of intense research, the molecular mechanisms involved in the pathology of lung injury from smoke inhalation are poorly illuminated $[1,2,5]$. Rats are model animals suitable for studying the effects of inhaled smoke on lung injury [8]. To study the potential mechanisms of smoke inhalation on lung injury, we developed a rat model with high doses of zinc chloride smoke inhalation to cause lung injury.

It is noted that isobaric tags for relative and absolute quantization (iTRAQ), mass spectrometry-based quantitative approaches and weighted gene co-expression network analysis (WGCNA) have largely contributed to proteomics investigations [9]. Applying the above techniques, we first analysed the differentially expressed proteins from days 1, 2, 7 and 14 after zinc chloride smoke inhalation in our rat model. Then, we further identified lung injury repair-related, differentially expressed proteins in the early and middle-late stages of lung injury. Our study may be helpful in understanding the potential molecular mechanisms in lung injuries due to smoke inhalation.

\section{Materials and methods}

\section{The lung injury rat model due to smoke inhalation}

Male Wistar rats with a weight of $200 \mathrm{~g}$ were supplied by the Academy of Military Medical Sciences of the PLA and were raised carefully in accordance with the ethical guidelines of the National Institutes of Health on animal care. All experimental procedures were approved by the Academy of Military Medical Sciences of the PLA. The homemade smoke chamber consisted of $5 \mathrm{~g}$ of smoke bomb materials (aluminium powder, zinc oxide, hexachloroethane, silicon powder and black powder). The smoke bomb was placed into a special rectangular iron pot with a diameter of $2 \mathrm{~cm}$, a magnesium strip was placed in the pot to ignite, and the smoke bomb was burned for approximately $45 \mathrm{~s}$. The smoke chamber is 1 $\mathrm{m}$ long, $0.8 \mathrm{~m}$ wide, $0.6 \mathrm{~m}$ high and $0.48 \mathrm{~m}^{3}$ in volume. The smoke box allows samples to be taken quickly, and these samples are measured by a gas sampler to determine the concentration of the individual smoke components in the gas. The concentration of the 5-g smoke bombs was 10.625 g.m-3. The gas sampling method was used to determine the concentration of the zinc ions in the smoke generated by the smoke bomb, and a concentration of $4.996 \mathrm{mg} / \mathrm{L}$ was determined. The male Wistar rats were randomly divided into the control group $(n=8)$ or the exposed group $(n=164)$, and the male Wistar rats in the exposed group were only exposed once on the first day for $5 \mathrm{~min}$, and then the smoke was cleared for $10 \mathrm{~min}$. In this study, the animals were only exposed once to a high dose because all human exposures are high-dose accidents and are not repeated occupational exposures. Lung tissues were collected 1, 2, 7, 14, 21 and 28 days after the initial exposure.

\section{Histopathology}

The right, upper lobe of the lung was fixed in $10 \%$ formalin, dehydrated, embedded in paraffin and cut into $6 \mu \mathrm{m}$ sections. After deparaffinization, the tissues were haematoxylin and eosin (H\&E) stained or Mallory stained, and the morphological lesions and changes in lung tissues were observed under a light microscope.

\section{Proteomics analysis}

Lung tissues were harvested and lysed in RIPA lysis buffer with protease inhibitors for $30 \mathrm{~min}$ at $4{ }^{\circ} \mathrm{C}$. Lysates were then centrifuged for $10 \mathrm{~min}$ at $12000 \mathrm{rpm}$ at $4{ }^{\circ} \mathrm{C}$, and the insoluble debris was discarded. The protein in the lung tissues was extracted, followed by alkylation treatment. The concentration test of the extracted protein was then performed. Sodium dodecyl sulfate was used for protein electrophoresis [10, 11]. Protein digestion was conducted using the filter-aided sample preparation (FASP) method described in Wisniewsk et al. [12]. After protein enzymolysis, the iTRAQ reagent was applied to mark peptides [10]. iTRAQ labelling was performed by using the iTRAQ reagent-8plex Multiplex Kit (AB Sciex California, USA) according to the manufacturer's instructions. Strong cation exchange chromatography was used to predissociate a balanced mixture of marked peptides [13]. The pooled samples were analysed by 2D LC-MS/MS. LC-electrospray ionization (ESI)-MS/ MS analysis was conducted on a liquid chromatography machine coupled with tandem mass spectrometry (nLC, Thermo Fisher Scientific). A $10-\mu \mathrm{L}$ aliquot of each fraction was injected for 2D LC-MS/MS analysis. A mass spectrometer (MS), (Orbitrap Fusion, Thermo Scientific) was 
used to analyse the eluted peptides. The MS data were acquired with the Orbitrap detector by using the fastest mode. For database searching, the differentially expressed proteins were identified with an abundance ratio $\geq 1.5$ or an abundance ratio $<0.667$ and $p$-values $\leq 0.05$. A heat-map analysis of the differentially expressed protein expression was performed by using pheatmap in R.

\section{Construction of the WGCNA co-expression network}

To find significant modules and proteins in the proteome data, the WGCNA package in the R software package (http://www.r-project.org/) was used to construct the co-expression network of the proteins. The rationale behind the WGCNA approach is that highly correlated genes, in terms of their expression values, are very likely to work in the same biological processes and/or pathways so that they can be grouped into a common network module [14]. The type of network is signed, which allows positively or negatively regulated genes to be grouped into different network modules. First, Pearson's correlation matrices were calculated between pairwise genes [15]. Then, the similarity matrix

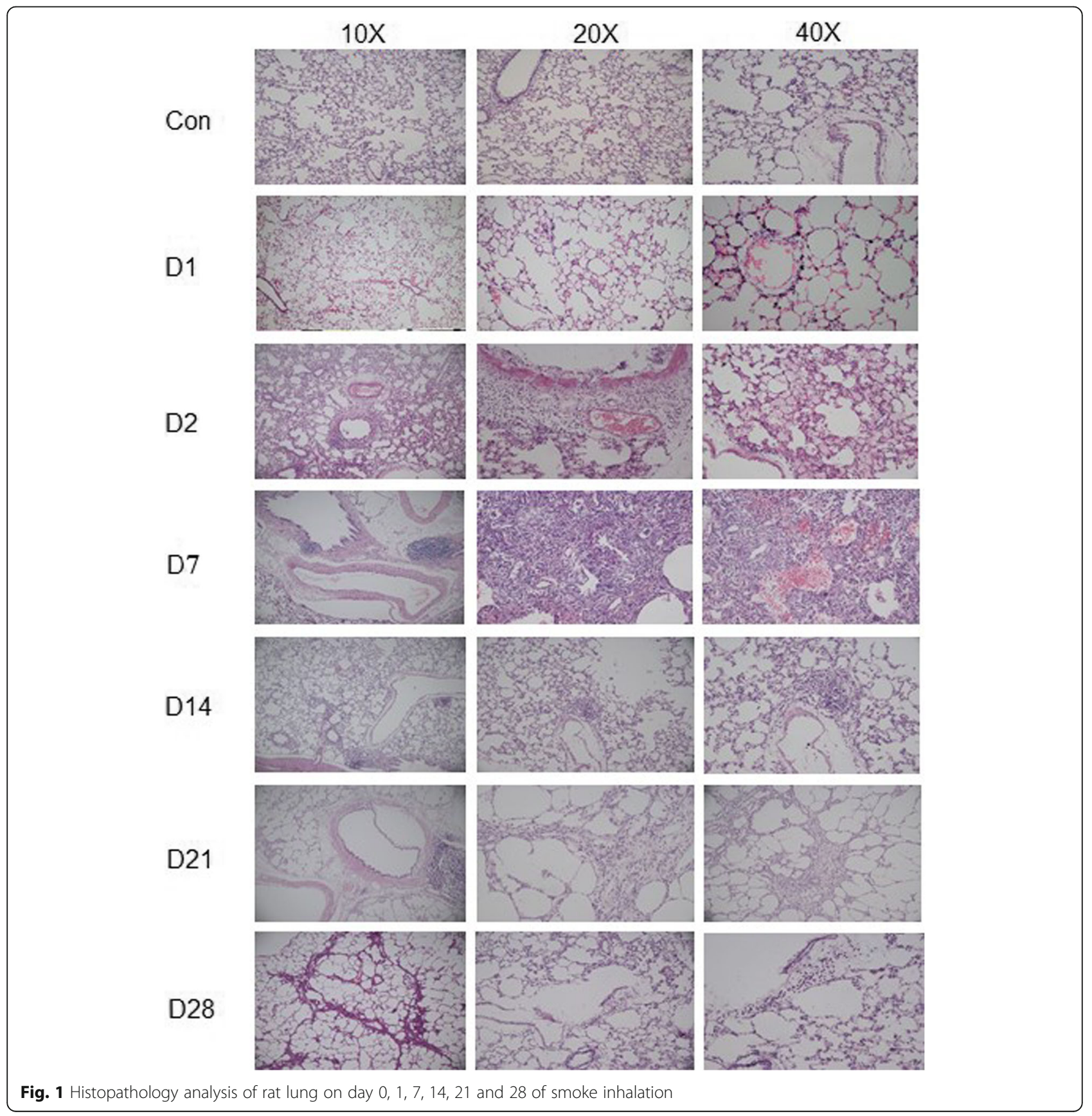


was transformed into an adjacency matrix (AM) using a power $\beta=10$ based on the scale-free topology criterion described in the WGCNA package documents [16]. Afterwards, the adjacency matrix was transformed into a topological overlap matrix and was, in turn, converted into a dissimilarity topological overlap matrix, from which a dendrogram was mapped via hierarchical clustering. The clusters were obtained from the dendrogram by using the dynamic tree cutting technique [17]. The next step was to further identify the most important modules for analysis. We first calculated the eigengene of each module, which is defined as the first principal component of its representation matrix. Then, we used these eigengenes to compute module-smoke inhalation time associations. The module-smoke inhalation time association for a given module and smoke inhalation time is the correlation between the eigengene of the module and the smoke inhalation time. Lastly, we chose six modules in association with the smoke inhalation times. In addition, to explore the association between the modules and the smoke inhalation times, a correlation analysis was performed. The modules with absolute values of correlation coefficients $>0.8$ and $p<0.001$ were identified to be smoke inhalation time-associated modules. The Cytoscape software (http://cytoscape.org/) was used for the visualization of the most significant time-associated module with a threshold $>0.5$. Cytoscape cores are available for layout, scripting, file formatting and linking the network to databases [18]. Nodes represent proteins, and edges represent interactions between two proteins [19]. The pivotal nodes in the network were identified based on their degrees of connectivity.

\section{Functional analysis of proteins in the turquoise module}

To study the biological function of proteins in the turquoise module, Gene Ontology (GO) and Kyoto Encyclopedia of Genes and Genomes (KEGG) pathway analyses were performed by using the online software GeneCodis3 (http://genecodis.cnb.csic.es/analysis). The false discovery rate (FDR) value of each enriched pathway was assigned with $-\log 10$ transformation. The threshold of the false discovery rate (FDR) $<0.05$ was set as the criteria for statistical significance.

\section{Identification of hub proteins in the turquoise module}

To further obtain key proteins, we screened hub differentially expressed proteins in the turquoise module. The proteins with Coefficient.Time + Coefficient.turquoise $>$ 0.9 , p.Time + p.turquoise $<0.01$ were identified to be hub proteins. A heat-map analysis of the expression of hub proteins was performed by using pheatmap in $R$ language.
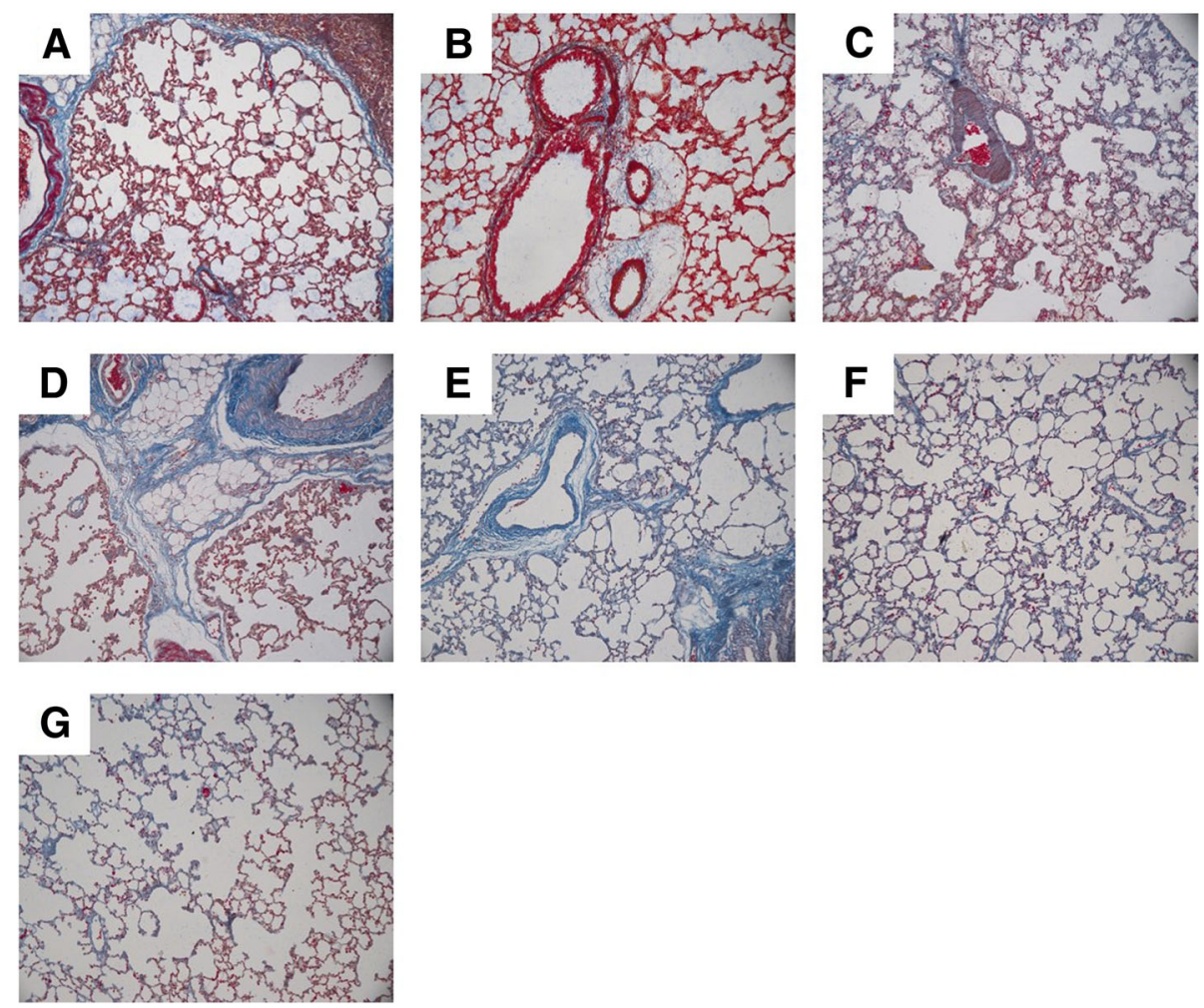

Fig. 2 Mallary staining analysis of rat lung on day $0,1,7,14,21$ and 28 of smoke inhalation. a Control. b Day 0 of smoke inhalation. c Day 1 of smoke inhalation. d Day 7 of smoke inhalation. e Day 14 of smoke inhalation. $\mathbf{f}$ Day 21 of smoke inhalation. $\mathbf{g}$ Day 28 of smoke inhalation 
Lung injury repair-related protein analysis in the early and middle-late stages of zinc chloride smoke inhalation To identify potential injury repair-related proteins and related signalling pathways in the early (day 1 and day 2 ) and middle-late (day 7 and day 14) stages of lung injury after smoke inhalation, we analysed the differentially expressed proteins on day 1 and day 2 compared with the control and on day 7 and day 14 compared with the control, respectively. All these key differentially expressed proteins intersected with those in the most significant smoke time-associated module.

\section{Protein-protein interaction analysis}

To understand the protein interaction between key differentially expressed proteins in the early (4 differentially expressed proteins) and middle-late (96 differentially expressed proteins) stages of smoke inhalation, the STRING database (http://www.string-db.org/) was utilized to select interacting protein pairs. Through the PPI relationship obtained in the previous step, the protein-protein network (PPI) was visualized by Cytoscape software (http://cytoscape.org/). The degree was analysed by Cytoscape software. In the network, the nodes represent proteins, and the edges represent the interactions between the two proteins.

\section{Immunohistochemistry validation of differentially expressed injury repair-related proteins}

In this study, PARK7, a differentially expressed protein on day 15 after smoke inhalation, was selected for immunohistochemistry (IHC) analysis on days 1, 2, 7, 14, 21 and 28. Then, $5 \mu \mathrm{m}$ thick continuous sections were incubated with an anti-PARK7 antibody produced in rabbit (1:200 dilution; Abcam) followed by goat anti-rabbit immunoglobulin antibody conjugated by horseradish peroxidase (1:200 dilution; Vector). Then, the slides were visualized using diaminobenzidine (DAB) substrate (Vector). The number of positive cells was calculated under the microscope.

\section{Western blot analysis of differentially expressed injury repair-related proteins}

In this study, the differentially expression proteins PARK7 and FABP5 after day 14 of smoke inhalation were selected for western blot (WB) analysis on days 1, 2, 7 and 14. Protein extracts were prepared by homogenization with protein lysates. Protein concentrations were quantified with an Enhanced BCA Protein Assay Kit (Thermo Fisher Scientific, Rochester, N.Y., USA). Protein samples were run on a $12 \%$ sodium dodecyl sulfate polyacrylamide gel for electrophoresis and were transferred to a polyvinylidene fluoride membrane.

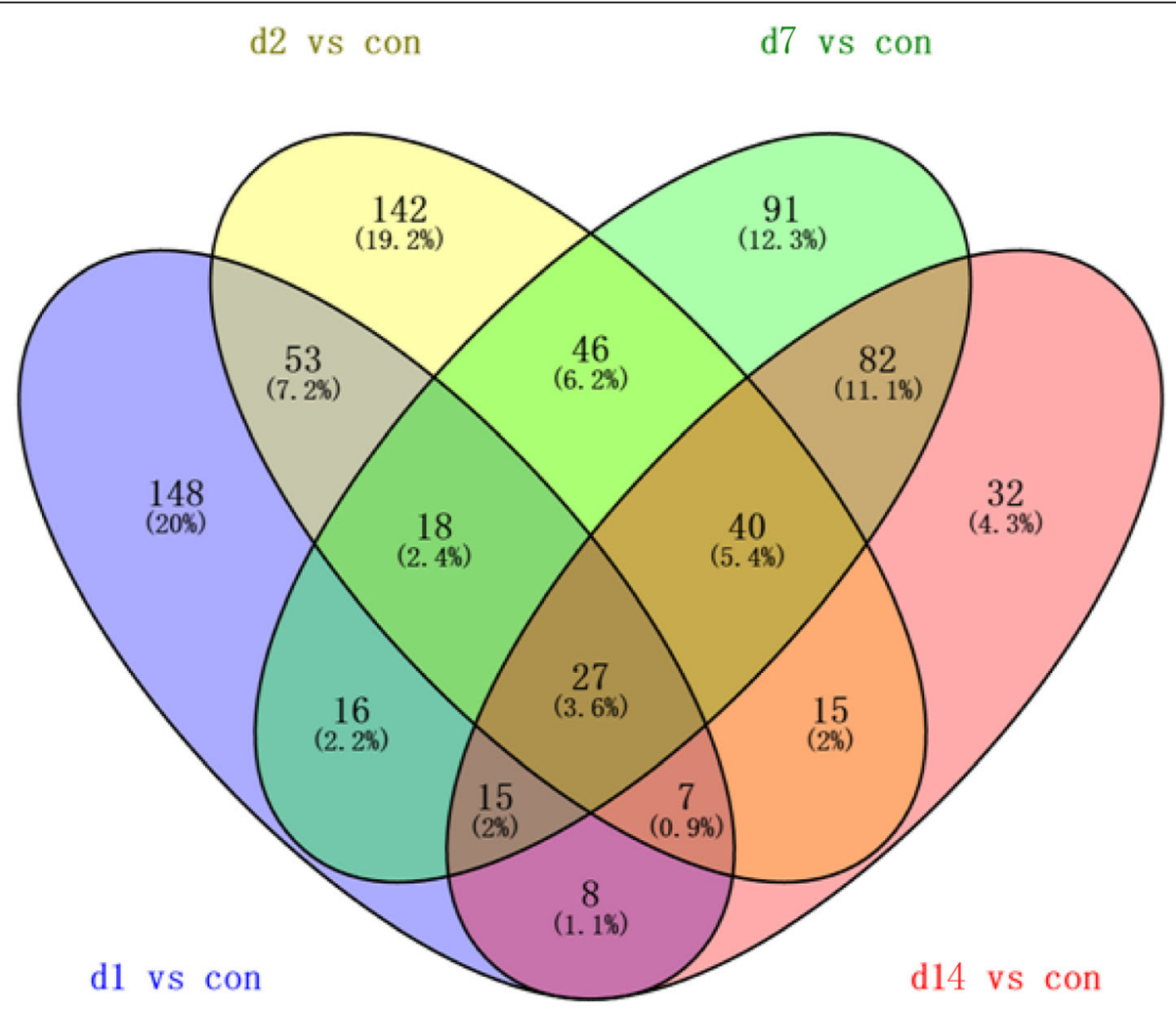

Fig. 3 The Venn diagram of differentially expressed proteins on day 1 vs control, day 2 vs control, day 7 vs control, and day 14 vs control 
The membrane was blocked with non-fat dried milk for $1 \mathrm{~h}$ and was incubated with the following primary antibodies: rabbit anti-human FABP5 (1:1000 dilution), rabbit anti-human PARK7 (1:500 dilution) and mouse monoclonal IgG1 to GAPDH (1:3000 dilution). Primary antibody binding was detected using horseradish peroxidase-conjugated secondary antibody (1:10000 dilution). Detection was achieved with the ECL chemiluminescence kit (Pierce). Bands from three separate western blots were analysed by Quantiscan software (Biosoft, Great Shelford, Cambridge, UK).

\section{Statistical analysis}

Immunohistochemistry and western blot statistical analyses were performed using GraphPad Prism (GraphPad Software, La Jolla, CA). Student's t-test was used to assess statistical significance. Statistical significance was ascribed to a $p$ value $<0.05$. Graphs are presented as the mean \pm SD. Immunohistochemistry and western blot experiments were repeated independently at least three times.

\section{Results}

Histopathology analysis of rat lungs after zinc chloride smoke inhalation

The histopathology analysis results of rat lungs after zinc chloride smoke inhalation are shown in Fig. 1. The control group showed a normal lung structure. On day 1 after smoke inhalation, vascular wall thickening, oedema, a large number of black particles around the lumen, and neutrophilic granulocytes increased. On day 2 after smoke inhalation, exudative pneumonia, a large amount of exudation in the alveolar cavity and infiltration of lymphocytes around the bronchioles were observed. On

Table 1 Twenty seven common differentially expressed proteins

\begin{tabular}{|c|c|c|c|c|c|c|c|c|c|c|c|c|}
\hline \multirow[b]{2}{*}{ Gene name } & \multicolumn{3}{|c|}{ Day 1 vs con } & \multicolumn{3}{|c|}{ Day 2 vs con } & \multicolumn{3}{|c|}{ Day 7 vs con } & \multicolumn{3}{|c|}{ Day 14 vs con } \\
\hline & Ratio & $p$ value & Regulated & Ratio & $p$ value & Regulated & Ratio & $p$ value & Regulated & Ratio & $p$ value & Regulated \\
\hline Adrm1 & 1.65 & 1.89E-02 & Up & 1.73 & $5.73 \mathrm{E}-03$ & Up & 1.69 & $6.66 \mathrm{E}-03$ & Up & 1.61 & $1.0 \mathrm{E}-02$ & Up \\
\hline Arl8b & 1.90 & 4.41E-03 & Up & 1.55 & $1.51 \mathrm{E}-02$ & Up & 1.83 & $3.74 \mathrm{E}-03$ & Up & 1.59 & $1.2 \mathrm{E}-04$ & Up \\
\hline Aspn & 0.53 & 8.46E-03 & Down & 0.39 & $5.02 \mathrm{E}-03$ & Down & 0.61 & $1.28 \mathrm{E}-02$ & Down & 0.56 & 9.3E-03 & Down \\
\hline Cenpv & 0.58 & 1.80E-03 & Down & 0.55 & 1.10E-03 & Down & 0.47 & $2.31 \mathrm{E}-03$ & Down & 0.60 & 2.1E-03 & Down \\
\hline Ckm & 0.46 & 1.87E-03 & Down & 2.00 & $1.85 \mathrm{E}-04$ & Up & 3.95 & 2.97E-05 & Up & 2.59 & $1.2 \mathrm{E}-04$ & Up \\
\hline Den & 0.64 & 2.49E-03 & Down & 0.59 & $5.31 \mathrm{E}-04$ & Down & 0.62 & 8.97E-04 & Down & 0.67 & $8.2 \mathrm{E}-04$ & Down \\
\hline $\operatorname{lgh}-1 \mathrm{a}$ & 0.55 & 7.01E-03 & Down & 0.63 & $9.74 \mathrm{E}-03$ & Down & 0.42 & $3.85 \mathrm{E}-03$ & Down & 0.53 & $6.1 \mathrm{E}-03$ & Down \\
\hline lgkv11-125 & 0.47 & $4.75 E-03$ & Down & 0.66 & $1.16 \mathrm{E}-02$ & Down & 0.35 & $2.93 \mathrm{E}-03$ & Down & 0.56 & 7.1E-03 & Down \\
\hline Lars & 1.73 & $4.24 \mathrm{E}-03$ & Up & 1.73 & 5.17E-03 & Up & 1.92 & $3.18 \mathrm{E}-03$ & Up & 1.57 & 8.1E-03 & Up \\
\hline Matn1 & 0.39 & $1.88 \mathrm{E}-02$ & Down & 0.16 & 9.66E-03 & Down & 0.45 & $2.11 \mathrm{E}-02$ & Down & 0.19 & $1.1 \mathrm{E}-02$ & Down \\
\hline Mpz & 0.47 & $1.22 \mathrm{E}-02$ & Down & 0.39 & 9.89E-03 & Down & 0.63 & $2.29 \mathrm{E}-02$ & Down & 0.48 & $1.2 \mathrm{E}-02$ & Down \\
\hline Mybpc3 & 0.52 & $6.43 \mathrm{E}-04$ & Down & 0.53 & $2.22 \mathrm{E}-03$ & Down & 0.65 & $4.52 \mathrm{E}-04$ & Down & 0.58 & $6.9 E-04$ & Down \\
\hline Myh6 & 0.37 & 4.17E-04 & Down & 0.37 & 4.01E-04 & Down & 0.48 & $6.89 \mathrm{E}-04$ & Down & 0.44 & 7.8E-04 & Down \\
\hline Myl3 & 0.66 & 4.53E-04 & Down & 1.66 & $1.22 \mathrm{E}-03$ & Up & 5.05 & $5.73 \mathrm{E}-04$ & Up & 3.21 & 1.1E-05 & Up \\
\hline Myl4 & 0.13 & 4.57E-04 & Down & 0.19 & $5.86 \mathrm{E}-04$ & Down & 0.37 & 2.70E-03 & Down & 0.13 & 3.7E-04 & Down \\
\hline Myl7 & 0.34 & $1.86 \mathrm{E}-04$ & Down & 0.39 & 2.39E-04 & Down & 0.50 & $6.95 \mathrm{E}-04$ & Down & 0.43 & $3.5 \mathrm{E}-04$ & Down \\
\hline Myoz2 & 0.40 & 3.63E-04 & Down & 0.54 & 5.03E-04 & Down & 0.63 & $1.44 \mathrm{E}-03$ & Down & 0.56 & 8.0E-04 & Down \\
\hline Ogn & 0.63 & 1.37E-03 & Down & 0.52 & 2.67E-05 & Down & 0.51 & 3.31E-05 & Down & 0.64 & $9.5 \mathrm{E}-05$ & Down \\
\hline Slc43a1 & 0.59 & 8.39E-03 & Down & 0.62 & $1.51 \mathrm{E}-04$ & Down & 0.54 & $1.14 \mathrm{E}-04$ & Down & 0.56 & $5.4 \mathrm{E}-03$ & Down \\
\hline Slc4a1 & 0.54 & 3.27E-03 & Down & 0.66 & $3.50 \mathrm{E}-03$ & Down & 0.48 & $1.55 \mathrm{E}-03$ & Down & 0.56 & $2.5 \mathrm{E}-03$ & Down \\
\hline Spta1 & 0.61 & $6.15 E-03$ & Down & 0.66 & 7.99E-03 & Down & 0.56 & 4.69E-03 & Down & 0.58 & 5.3E-03 & Down \\
\hline Tecrl & 0.50 & 5.89E-03 & Down & 0.48 & 5.36E-03 & Down & 0.62 & $1.27 \mathrm{E}-02$ & Down & 0.50 & 1.6E-02 & Down \\
\hline Tnnc1 & 0.29 & $1.50 \mathrm{E}-03$ & Down & 0.44 & $1.63 \mathrm{E}-04$ & Down & 0.43 & $2.31 \mathrm{E}-04$ & Down & 0.46 & $1.2 \mathrm{E}-03$ & Down \\
\hline Tnni3 & 0.39 & $1.00 \mathrm{E}-03$ & Down & 0.32 & $1.23 \mathrm{E}-03$ & Down & 0.46 & $1.18 \mathrm{E}-03$ & Down & 0.40 & 7.2E-04 & Down \\
\hline Tnnt2 & 0.41 & $1.96 \mathrm{E}-03$ & Down & 0.41 & $3.17 \mathrm{E}-03$ & Down & 0.52 & 7.71E-03 & Down & 0.43 & $2.2 \mathrm{E}-03$ & Down \\
\hline Trpm7 & 0.40 & 4.68E-03 & Down & 0.53 & 8.78E-03 & Down & 0.54 & 9.93E-03 & Down & 0.51 & 9.9E-03 & Down \\
\hline Tsga10 & 0.54 & 4.55E-02 & Down & 0.46 & $1.52 \mathrm{E}-02$ & Down & 0.47 & $1.59 \mathrm{E}-02$ & Down & 0.51 & 2.0E-02 & Down \\
\hline
\end{tabular}


day 8 after smoke inhalation, bleeding, emphysema, obvious cavities around the blood vessels, fibroblast proliferation, and massive lymphocytes in the alveolar cavity were observed. On day 14 after smoke inhalation, the alveolar cavity was obviously dilated, and scattered inflammatory foci were visible. On day 21 after smoke inhalation, the bronchial wall dilated and developed into an interstitial emphysema. The alveolar sac was extremely dilated, the interstitial sac was obviously widened, and there was a large amount of inflammatory cell infiltration. On day 28 after smoke inhalation, fibrous tissue hyperplasia, pulmonary fibrosis, eosinophilic infiltration of alveolar cavities, and alveolar expansion were observed.

\section{Mallory staining analysis of rat lungs after smoke inhalation}

The Mallory method was used for tricolour staining of lung tissues. The Mallory staining results of rat lungs after smoke inhalation are shown in Fig. 2. The dark blue substance was significantly increased in lung tissues on days 1 (B), 2 (C), 7 (D), 14 (E), 21 (F) and 28 (G) after smoke inhalation compared with that in the control group (A), indicating that pulmonary fibrosis occurred after smoke inhalation.

\section{Identification of differentially expressed proteins}

In this study, a proteomics analysis was used for differentially expressed protein identification in lung tissues on days 1, 2, 7 and 14 after smoke inhalation. A total of 3377 differentially expressed proteins were identified. Among these, 27 common differentially expressed proteins were obtained on days 1, 2, 7 and 14 after smoke inhalation. A Venn diagram of the differentially expressed proteins on day 1 vs day 0 , day 2 vs day 0 , day 7 vs day 0 and day 14 vs day 0 is shown in Fig. 3. In addition, 27 common differentially expressed proteins are listed in Table 1. Figure 4 shows the heat map of the 27 common differentially expressed proteins.

\section{WGCNA co-expression network analysis}

In the WGCNA co-expression network analysis, a total of 6 modules (green, blue, yellow, brown, turquoise and grey) were identified (Fig. 5). To further explore the correlation between the modules and the smoke inhalation time, a correlation analysis was performed, and the modules with a correlation coefficient $>0.8$ and $p<0.001$ were considered to be related. The correlation analysis showed that the turquoise module (which had 909 proteins) was associated with smoke inhalation time, and the other modules were not related to smoke inhalation time $(p>0.05)$, as shown in Table 2. In addition, the visualization of the turquoise module, which consists of 76 nodes and 370 edges, is shown in Fig. 6.

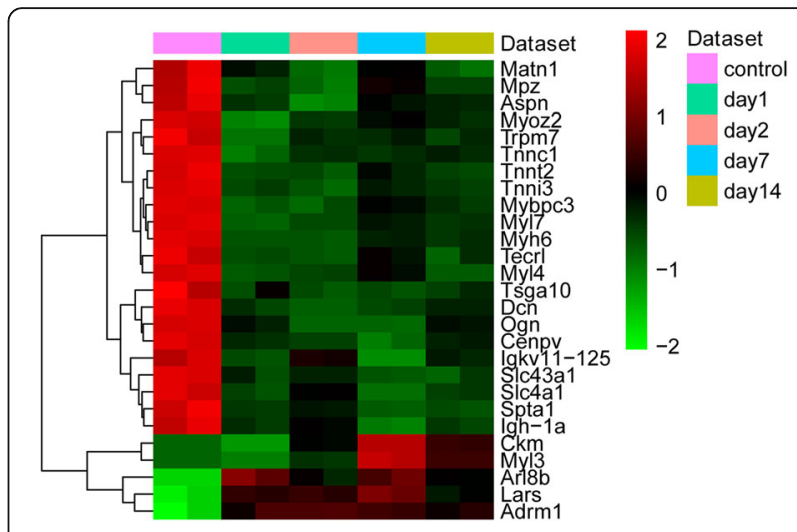

Fig. 4 The heat map of 27 common differentially expressed proteins on day 1, 2, 7 and 14. Diagram presents the result of a two-way hierarchical clustering of 27 common differentially expressed proteins and time points. The clustering is constructed using the complete-linkage method together with the Euclidean distance. Each row represents a differentially expressed protein and each column, a time point. Differentially expressed protein clustering tree is shown on the right. The colour scale illustrates the relative level of differentially expressed protein expression: red, below the reference channel; green, higher than the reference

Functional annotation of the turquoise module According to the GO enrichment analysis (Fig. 7), protein folding, metabolic processes and proteolysis were the most significantly enriched biological processes; the cytoplasm, mitochondria, and cytosol were the most significantly enriched cellular components; nucleotide binding, ATP binding and peptidase activity were the most significantly enriched molecular functions. In addition, based on the KEGG enrichment analysis, proteasome, protein processing in endoplasmic reticulum, lysosome and glycolysis/gluconeogenesis were enriched signaling pathways (Table 3 ).

\section{Hub protein identification in the turquoise module}

To further identify important proteins, we screened the hub proteins in the turquoise module. A total of 55 hub proteins were identified (Table 4). Additionally, the heat map of 55 hub proteins is shown in Fig. 8. In Fig. 8, 55 differentially expressed hub proteins were significantly upregulated on day 7 and day 14 (middle-late stage) after smoke inhalation, which suggests that these proteins may be associated with lung injury repair from smoke inhalation.

Injury repair-related differentially expressed proteins analysis in the early and middle-late stages of zinc chloride smoke inhalation

The histopathology results showed obvious lung injury on day 1 and day 2 after zinc chloride smoke inhalation. Therefore, it is necessary to find smoke inhalation lung injury repair-related differentially expressed proteins and 


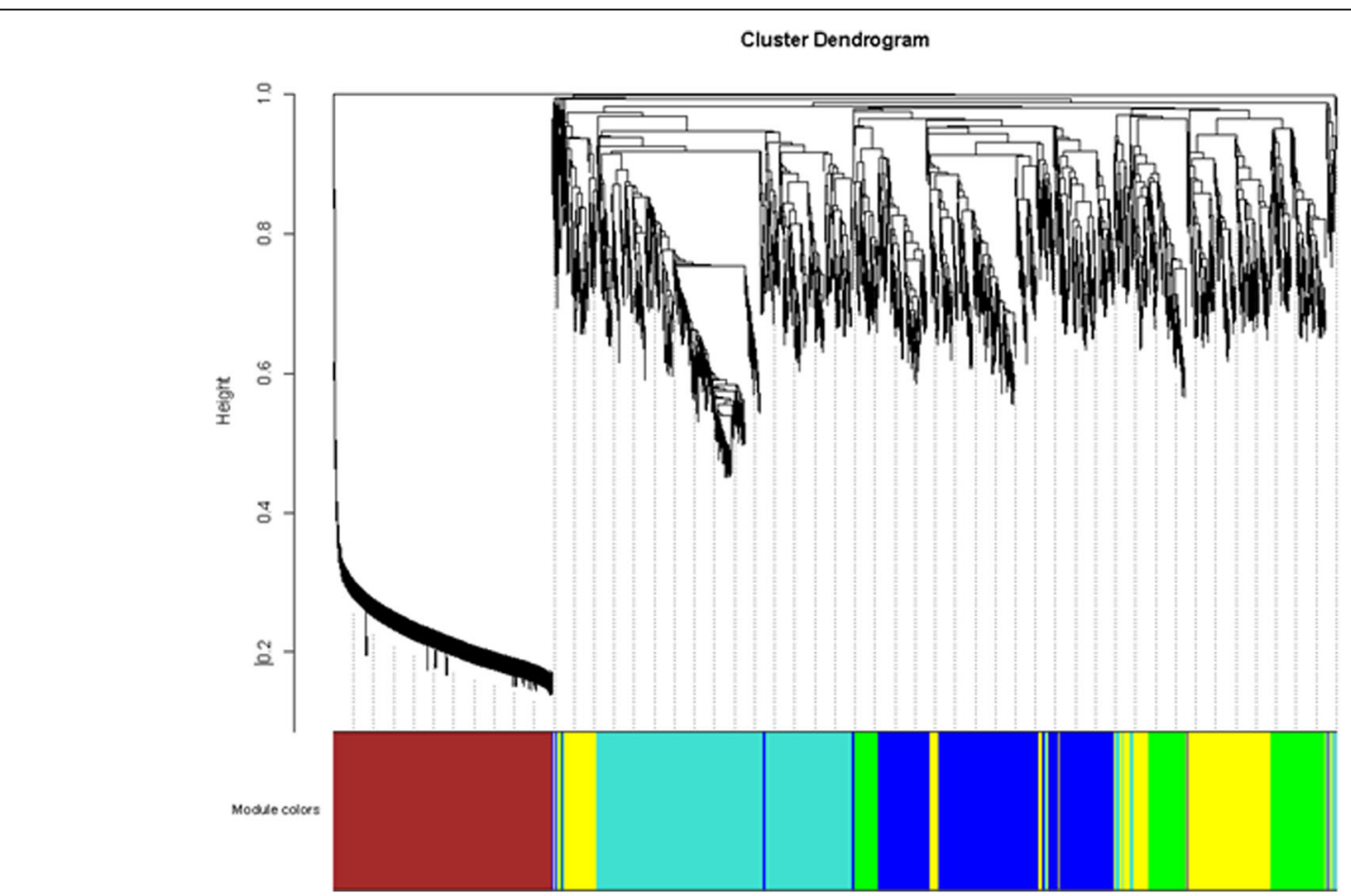

Fig. 5 Clustering results of modules in proteome data. Genes in modules are marked with different colors (green, blue, yellow, brown, turquoise and grey). The lower panel shows colors designated for each module

related signalling pathways in the early and middle-late stages of smoke inhalation. A total of 4 differentially expressed proteins, including Myl3, Ckm, Adrm1 and Igfbp7, were identified after overlapping the early stage of injury with the turquoise module after smoke inhalation. In addition, a total of 96 proteins were identified after overlapping the middle-late stage of injury from smoke inhalation with the turquoise module. A Venn diagram of related differentially expressed proteins in the early and middle-late stages of smoke inhalation is shown in Fig. 9. In addition, after KEGG enrichment analysis of these 96 differentially expressed proteins, we found that the lysosome, glycolysis/gluconeogenesis pathway (involving Eno3 and Tpi1), pentose phosphate pathway, amino sugar and nucleotide sugar metabolism, dust collection duct acid secretion, fructose and mannose metabolism, starch and sucrose metabolism and

Table 2 The correlation analysis between modules and smog inhalation time

\begin{tabular}{lll}
\hline Module & Correlation coefficient & $p$ value \\
\hline green & -0.35 & 0.32 \\
blue & -0.09 & 0.81 \\
yellow & -0.33 & 0.35 \\
brown & 0.0029 & 0.99 \\
turquoise & 0.88 & 0.00086 \\
grey & -0.031 & 0.93 \\
\hline
\end{tabular}

citrate cycle (TCA cycle) were the enriched signalling pathways (Table 5).

\section{PPI network}

The PPI network of identified key differentially expressed proteins in the early stage (4 differentially expressed proteins were identified after overlapping the early stage of smoke inhalation with the turquoise module) and middle-late stage (96 differentially expressed proteins were identified after overlapping the middle-late of smoke inhalation with the turquoise module) of smoke inhalation was determined by Cytoscape software. There were 61 nodes and 205 edges in the network (Fig. 10). Interestingly, Eno3 (degree $=20$ ), Gapdh $($ degree $=19)$, Acly $($ degree $=17)$, Umps $($ degree $=17)$, Tpi1 $($ degree $=15)$, Pygm $($ degree $=15)$, Tnni2 $($ degree $=$ 15), Actn3 (degree =15), and Acta1 (degree $=15)$ were proteins with a high degree of differential expression.

\section{Immunohistochemistry validation of PARK7}

In this study, PARK7, a differentially expressed protein after day 14 of smoke inhalation, was selected for IHC analysis on days 1, 2, 8, 14, 21 and 28 (Fig. 11). The brown colour represents the positive staining of PARK7. The expression of PARK7 was mainly located in the cytoplasm and the nucleus. Moreover, the density of PARK7 staining in the nucleus increased over time after smoke inhalation. The strong positive staining signal 


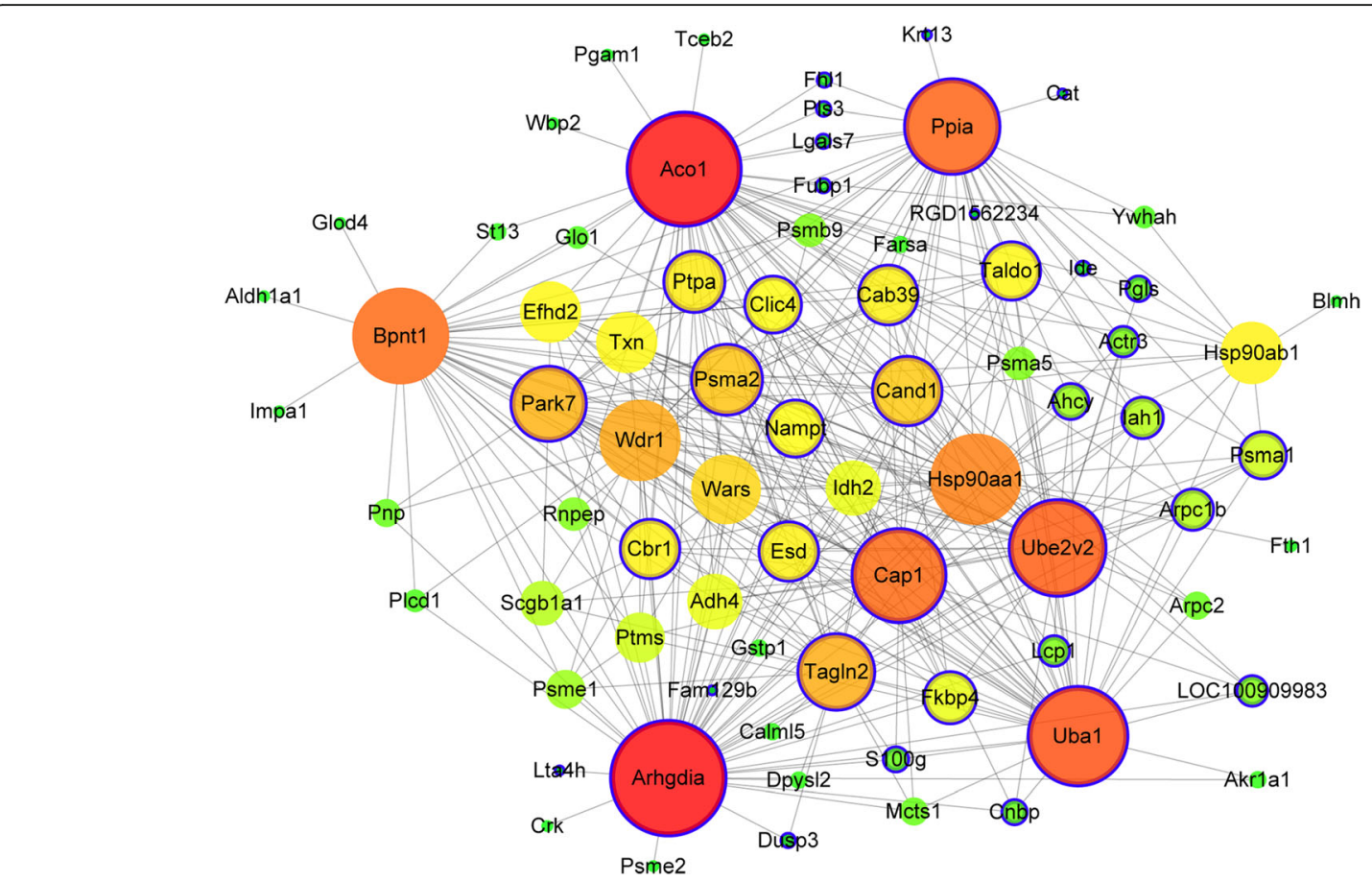

Fig. 6 The visualization of the turquoise module in the WGCNA co-expression network. The larger circle represents the higher degree protein. The blue border indicates hub protein

(especially in the control group) was located in the bronchial epithelial cells and the alveolar epithelial cells. The validation result of PARK7 was consistent with the results of the proteomics analysis.

\section{Western blot analysis of PARK7 and FABP5}

In this study, the differentially expressed proteins PARK7 and FABP5 on day 14 after smoke inhalation were selected for WB analysis on days 1, 2, 7 and 14 (Fig. 12).
The expression of PARK7 was highest in the control group and decreased with the smoke inhalation time. The expression of FABP5 was highest on day 14. The validation result is consistent with the proteomics analysis.

\section{Discussion}

Since the first case of smoke bomb inhalation injury was reported in 1945, cases of smoke-induced inhalation

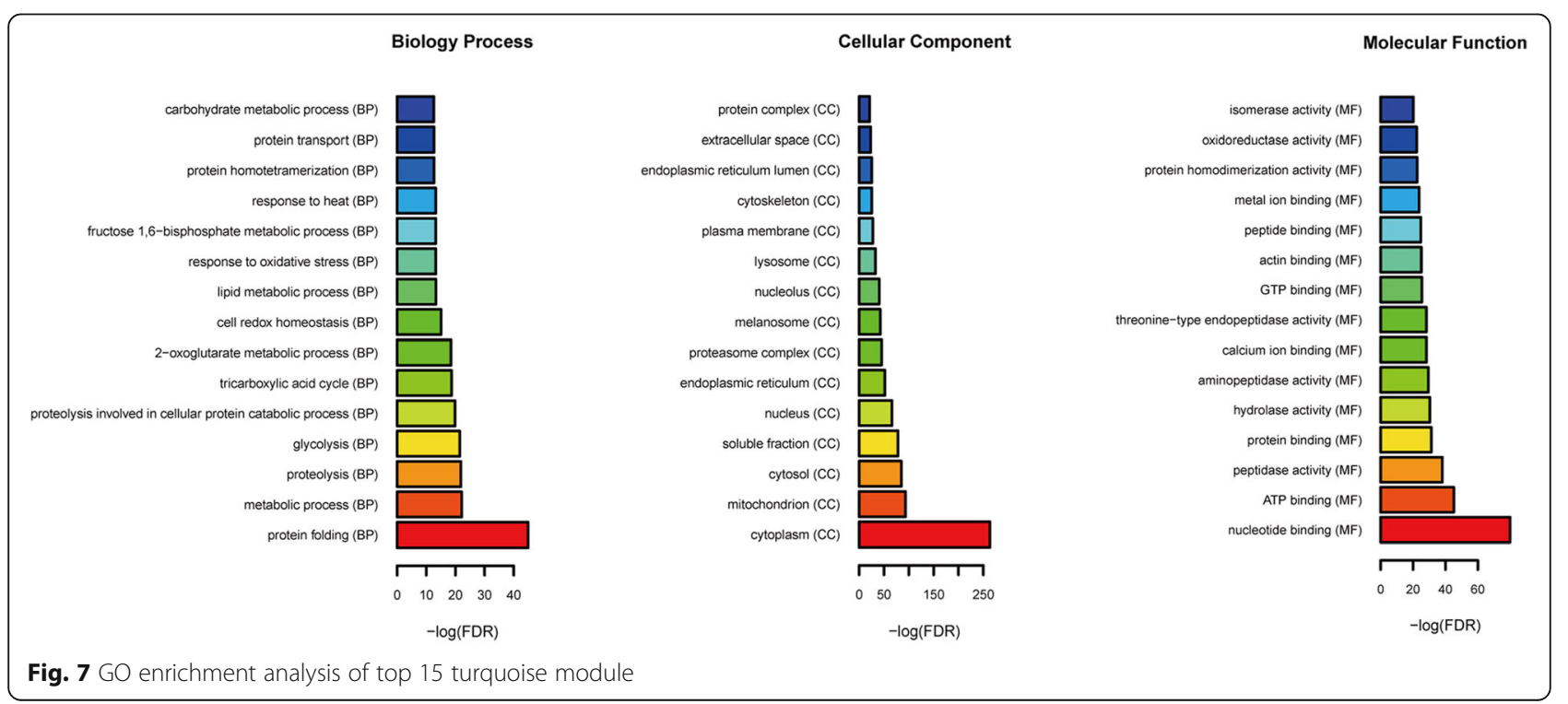




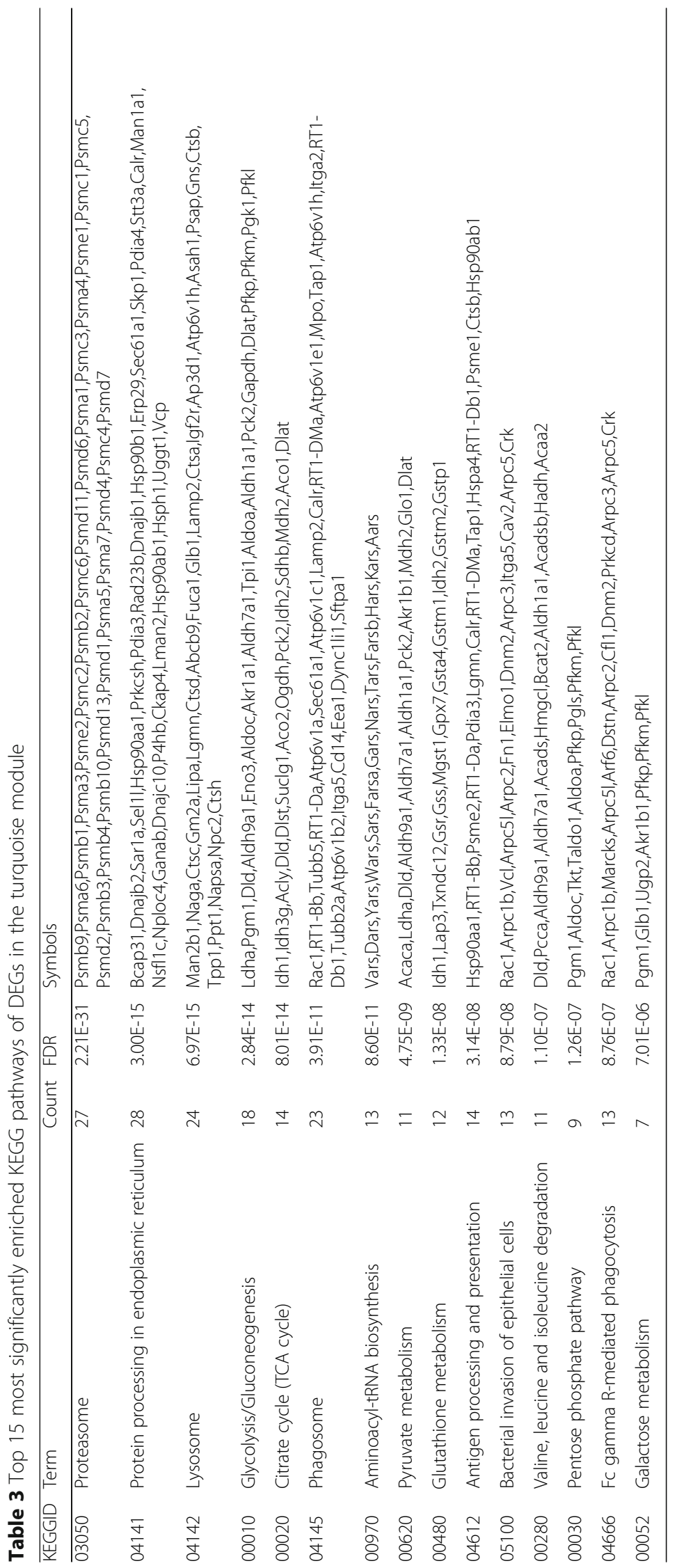


Table 4 Fifty five hub proteins in the turquoise module

\begin{tabular}{|c|c|c|c|c|}
\hline Protein & Coefficient.Time & p.Time & Coefficient.turquoise & p.turquoise \\
\hline Aars & 0.90 & 3.37E-04 & 0.90 & 3.63E-04 \\
\hline Acol & 0.90 & $3.25 \mathrm{E}-04$ & 0.98 & 7.60E-07 \\
\hline Actn3 & 0.97 & $2.02 \mathrm{E}-06$ & 0.92 & 1.39E-04 \\
\hline Actr3 & 0.95 & 2.61E-05 & 0.96 & $7.56 \mathrm{E}-06$ \\
\hline Adk & 0.98 & $9.53 \mathrm{E}-07$ & 0.90 & $3.76 \mathrm{E}-04$ \\
\hline Ahcy & 0.96 & $1.06 \mathrm{E}-05$ & 0.94 & $4.02 \mathrm{E}-05$ \\
\hline Apobec2 & 0.97 & $2.29 \mathrm{E}-06$ & 0.91 & 2.60E-04 \\
\hline Aprt & 0.90 & $3.38 \mathrm{E}-04$ & 0.97 & 4.13E-06 \\
\hline Arhgdia & 0.92 & $1.50 \mathrm{E}-04$ & 0.95 & $1.96 \mathrm{E}-05$ \\
\hline Arpclb & 0.96 & $1.58 \mathrm{E}-05$ & 0.95 & $1.94 \mathrm{E}-05$ \\
\hline Cab39 & 0.90 & $3.69 \mathrm{E}-04$ & 0.96 & $1.64 \mathrm{E}-05$ \\
\hline Cand1 & 0.92 & $2.03 \mathrm{E}-04$ & 0.97 & 4.51E-06 \\
\hline Cap1 & 0.91 & $2.12 \mathrm{E}-04$ & 0.96 & $1.56 \mathrm{E}-05$ \\
\hline Cat & 0.96 & $6.79 \mathrm{E}-06$ & 0.94 & $5.44 \mathrm{E}-05$ \\
\hline Cbr1 & 0.90 & $3.38 \mathrm{E}-04$ & 0.93 & $1.01 \mathrm{E}-04$ \\
\hline Clic4 & 0.92 & $1.44 \mathrm{E}-04$ & 0.95 & 3.05E-05 \\
\hline Cnbp & 0.91 & $2.98 \mathrm{E}-04$ & 0.91 & 2.91E-04 \\
\hline Cndp2 & 0.94 & 5.04E-05 & 0.95 & 3.64E-05 \\
\hline Dusp3 & 0.92 & $1.56 \mathrm{E}-04$ & 0.91 & 2.73E-04 \\
\hline Eno3 & 0.94 & $6.44 \mathrm{E}-05$ & 0.91 & $2.59 \mathrm{E}-04$ \\
\hline Esd & 0.92 & 1.47E-04 & 0.92 & $1.86 \mathrm{E}-04$ \\
\hline Fabp5 & 0.96 & 1.67E-05 & 0.97 & $3.15 \mathrm{E}-06$ \\
\hline Fam129b & 0.96 & 1.10E-05 & 0.92 & $1.34 \mathrm{E}-04$ \\
\hline Fhl1 & 0.93 & $7.42 \mathrm{E}-05$ & 0.98 & $2.58 \mathrm{E}-07$ \\
\hline Fkbp4 & 0.94 & 4.15E-05 & 0.91 & $2.41 \mathrm{E}-04$ \\
\hline Fubp1 & 0.92 & $1.32 \mathrm{E}-04$ & 0.97 & 2.19E-06 \\
\hline Gars & 0.91 & $2.89 \mathrm{E}-04$ & 0.97 & $3.48 \mathrm{E}-06$ \\
\hline lah1 & 0.94 & $5.64 \mathrm{E}-05$ & 0.93 & 7.31E-05 \\
\hline Ide & 0.97 & $2.21 \mathrm{E}-06$ & 0.94 & 4.85E-05 \\
\hline Krt13 & 0.95 & $3.25 \mathrm{E}-05$ & 0.98 & $6.44 \mathrm{E}-07$ \\
\hline Lcp1 & 0.97 & 3.50E-06 & 0.93 & 9.37E-05 \\
\hline Lgals7 & 0.94 & 5.41E-05 & 0.97 & 3.31E-06 \\
\hline LOC100909983 & 0.95 & $2.22 \mathrm{E}-05$ & 0.92 & $1.54 \mathrm{E}-04$ \\
\hline Lta4h & 0.98 & 1.13E-06 & 0.92 & $1.58 \mathrm{E}-04$ \\
\hline Mapk15 & 0.92 & 2.03E-04 & 0.99 & $5.66 \mathrm{E}-08$ \\
\hline Mtpn & 0.94 & $6.40 \mathrm{E}-05$ & 0.90 & $3.20 \mathrm{E}-04$ \\
\hline Mybpc2 & 0.94 & $3.94 \mathrm{E}-05$ & 0.96 & 1.19E-05 \\
\hline Myoz1 & 0.93 & 1.05E-04 & 0.93 & 7.84E-05 \\
\hline Nampt & 0.93 & 1.11E-04 & 0.91 & $2.44 \mathrm{E}-04$ \\
\hline Park7 & 0.92 & 1.33E-04 & 0.94 & $4.58 \mathrm{E}-05$ \\
\hline Pgls & 0.93 & 7.55E-05 & 0.98 & $1.38 \mathrm{E}-06$ \\
\hline Pls3 & 0.92 & $1.89 \mathrm{E}-04$ & 0.96 & $1.68 \mathrm{E}-05$ \\
\hline Ppia & 0.91 & $2.08 \mathrm{E}-04$ & 0.99 & 9.95E-08 \\
\hline Psma1 & 0.91 & 2.73E-04 & 0.97 & $4.48 \mathrm{E}-06$ \\
\hline
\end{tabular}


Table 4 Fifty five hub proteins in the turquoise module (Continued)

\begin{tabular}{lllll}
\hline Protein & Coefficient.Time & p.Time & Coefficient.turquoise & p.turquoise \\
\hline Psma2 & 0.92 & $1.76 \mathrm{E}-04$ & 0.96 & $8.57 \mathrm{E}-06$ \\
Psmc4 & 0.92 & $1.58 \mathrm{E}-04$ & 0.92 & $1.80 \mathrm{E}-04$ \\
Ptpa & 0.91 & $3.16 \mathrm{E}-04$ & 0.94 & $4.96 \mathrm{E}-05$ \\
RGD1562234 & 0.95 & $3.02 \mathrm{E}-05$ & 0.97 & $2.06 \mathrm{E}-06$ \\
S100 g & 0.97 & $2.12 \mathrm{E}-06$ & 0.91 & $3.16 \mathrm{E}-04$ \\
Set & 0.92 & $1.76 \mathrm{E}-04$ & 0.94 & $5.02 \mathrm{E}-05$ \\
Tagln2 & 0.94 & $5.04 \mathrm{E}-05$ & 0.94 & $6.72 \mathrm{E}-05$ \\
Taldo1 & 0.95 & $3.36 \mathrm{E}-05$ & 0.95 & $2.53 \mathrm{E}-05$ \\
Tprkb & 0.91 & $2.87 \mathrm{E}-04$ & 0.97 & $2.96 \mathrm{E}-06$ \\
Uba1 & 0.92 & $1.75 \mathrm{E}-04$ & 0.97 & $5.91 \mathrm{E}-06$ \\
Ube2v2 & 0.91 & $2.34 \mathrm{E}-04$ & 0.97 & $2.26 \mathrm{E}-06$ \\
\hline
\end{tabular}

lung injuries have been continuously reported [20]. Zinc chloride is often used for battle, military exercises, and fire-fighting training [21]. Zinc chloride aerosols are highly hygroscopic in the respiratory tract. Both the inhalation of the smoke and zinc chloride lead to pulmonary oedema, alveolitis in the early phase, late-phase pulmonary fibrosis, and often fatal acute respiratory distress syndrome in confined spaces [20, 22]. Smoke inhalation injury has a complex pathogenesis, and there is no specific treatment. Current animal models for studying inhaled lung injuries mainly include rats, ovines and rabbits [23-25]. Rats are easy to breed and are easy

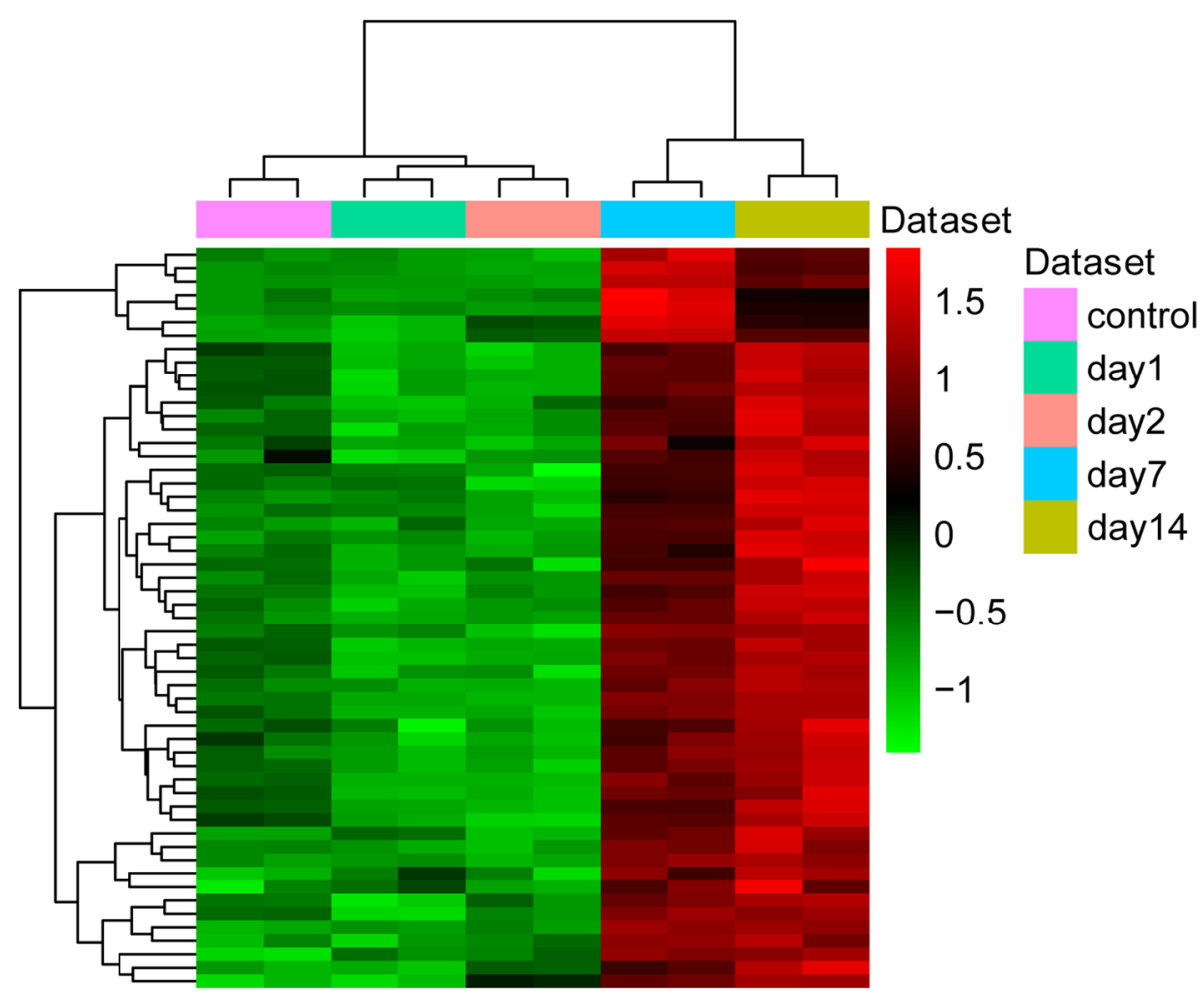

Fig. 8 The heat map of 55 hub proteins in the turquoise module. Diagram presents the result of a two-way hierarchical clustering of 55 hub differentially expressed proteins and time points. The clustering is constructed using the complete-linkage method together with the Euclidean distance. Each row represents a hub differentially expressed protein and each column, a time point. The hub differentially expressed protein clustering tree is shown on the right. The colour scale illustrates the relative level of hub protein expression: red, below the reference channel; green, higher than the reference 

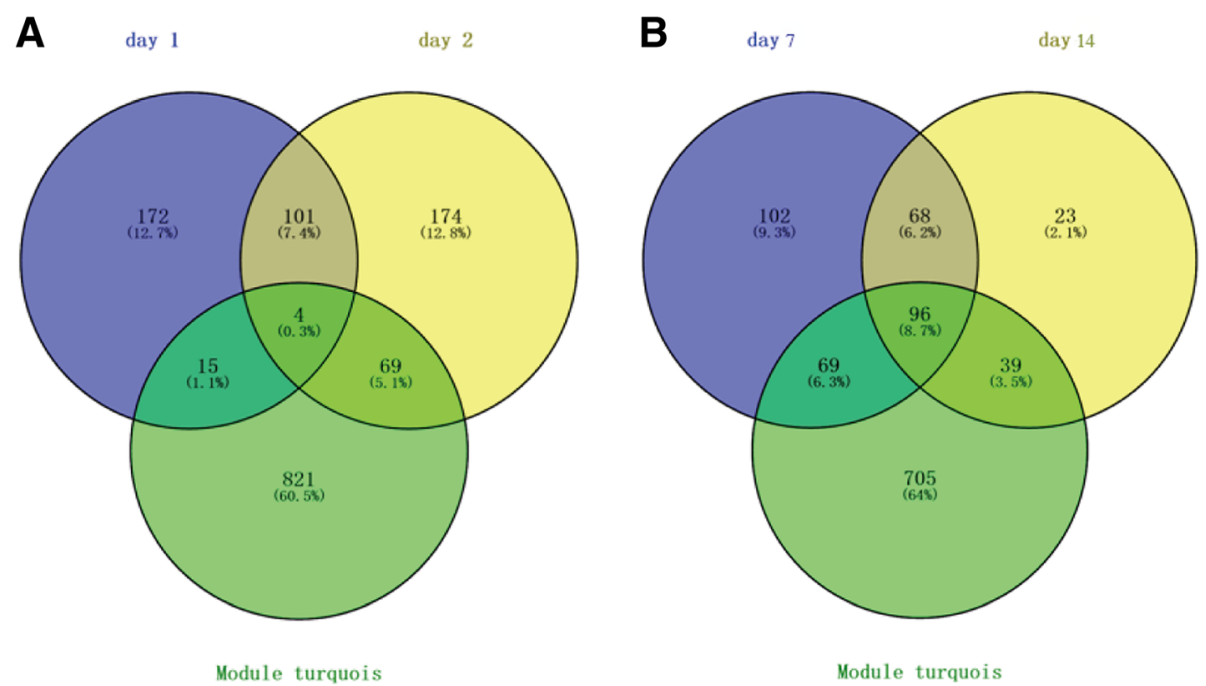

Fig. 9 The Venn diagram of related differentially expressed proteins analysis in the early and middle-late stage of smoke inhalation. a early stage of smoke inhalation. $\mathbf{b}$ middle-late stage of smoke inhalation

to develop into model animals for studying various diseases. Zhu et al. reported that the rat model of inhaled smoke is particularly suitable for studying the effects of long-term inhalation of smoke on lung injury [8]. With high-throughput analysis, the emergence of profiles has become an effective method to identify differentially expressed genes and proteins in a variety of diseases. These profiles help to explore pathogenesis and to develop biomarkers. A high-throughput sequencing analysis has suggested that circRNAs were differentially expressed during acute lung injury induced by smoke inhalation in rat lung tissue [23]. To our knowledge, this is the first time that differential proteins have been identified after an inhaled lung injury in rats using proteomic analysis. Here, we established a model of rat zinc chloride smoke inhalation to define proteins associated with inhaled lung injury. In this study, we explored the histopathology of rat lungs after zinc chloride smoke inhalation. On day 1 of smoke inhalation, lung injury occurred. On day 7 after smoke inhalation, injury repair began. On day 14 after smoke inhalation, repair to the injury was obvious. This suggested that smoke inhalation had an effect on the lungs. In addition, after the WGCNA co-expression network analysis, we finally obtained a total of 55 differentially expressed hub proteins. Interestingly, 55 hub proteins were upregulated on days 7 and 14 after smoke inhalation, which suggests that these proteins may be associated with injury repair. Based on this, we further analysed the differentially expressed proteins related to lung injury repair in the early (day 1 and day 2) and middle-late (day 7 and day 14) stages after smoke inhalation. Finally, a total of 4 proteins, including $\mathrm{Ckm}$, Adrm1, Igfbp7 and Myl3, were identified in the early stages of lung injury after smoke inhalation.

Creatine kinase muscle $(\mathrm{Ckm})$ is an early, sensitive tissue leakage biomarker of skeletal muscle injury [26]. Adhesion regulating molecule 1 (Adrm1) encodes the

Table 5 KEGG analysis of 96 differentially expressed proteins in the middle-late stage of inhalation lung injury

\begin{tabular}{lllll}
\hline KEGG ID & Term & Count & FDR & Symbols \\
\hline 04142 & Lysosome & 8 & $1.99 E-08$ & Ctsc,Gm2a,Lgmn,Ctsd,Fuca1,Napsa,Npc2,Ctsh \\
00010 & Glycolysis/Gluconeogenesis & 6 & $1.84 \mathrm{E}-07$ & Ldha,Pgm1,Eno3,Tpi1,Aldoa,Gapdh \\
00030 & Pentose phosphate pathway & 4 & $1.18 \mathrm{E}-05$ & Pgm1,Tkt,Taldo1,Aldoa \\
00520 & Amino sugar and nucleotide sugar metabolism & 3 & $2.94 \mathrm{E}-03$ & Pgm1,Uap1,Uap1l1 \\
04966 & Collecting duct acid secretion & 2 & $2.12 \mathrm{E}-02$ & Atp6v1c1,Atp6v1e1 \\
00051 & Fructose and mannose metabolism & 2 & $2.16 \mathrm{E}-02$ & Tpi1,Aldoa \\
00500 & Starch and sucrose metabolism & 2 & $2.18 \mathrm{E}-02$ & Pgm1,Pygm \\
00020 & Citrate cycle (TCA cycle) & 2 & $2.37 \mathrm{E}-02$ & Idh1,Acly \\
\hline
\end{tabular}




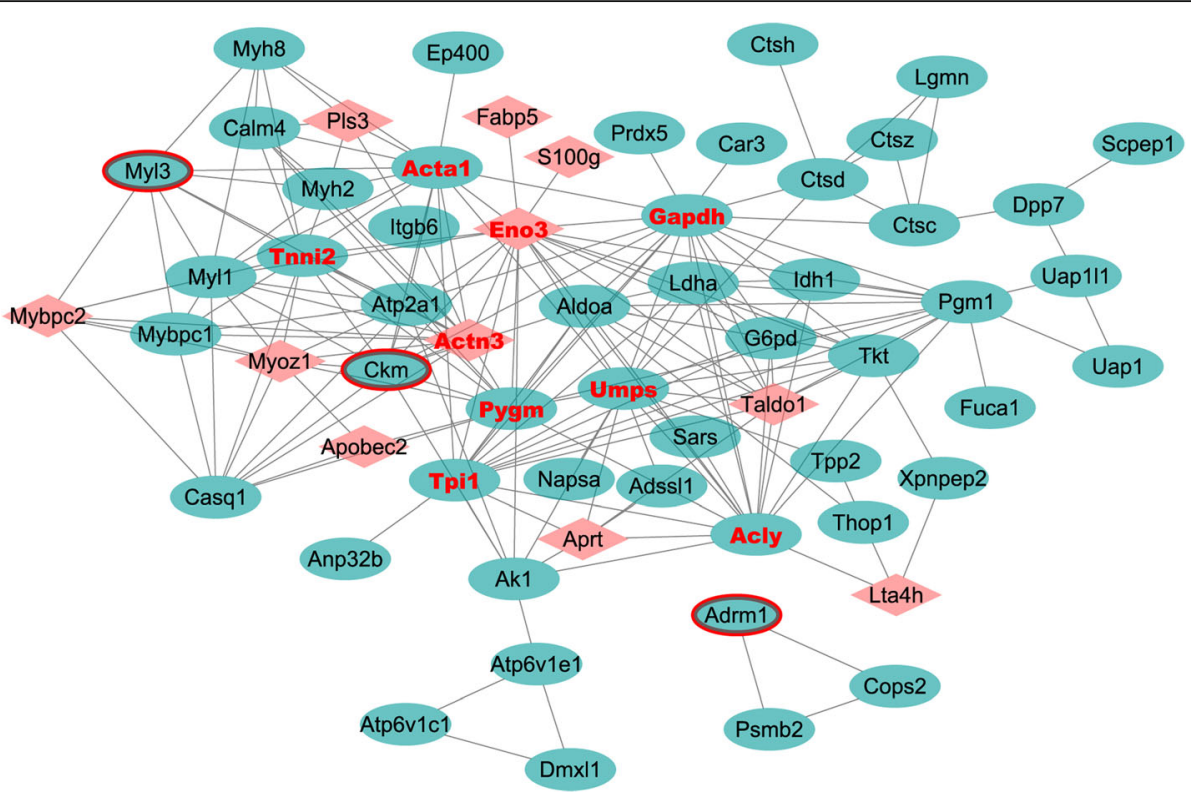

Fig. 10 PPI networks of key differentially expressed proteins in the early and middle-late stage of smoke inhalation. Red triangle represents the hub protein in the WGCNA analysis; Red border represents the common differentially expressed proteins on day 1, 2, 7 and 14; Red font represents the protein with a high degree in the PPI network

integral plasma membrane protein involved in proteolysis and deubiquitination [27-30]. It has been reported that Adrm1 is downregulated in ageing-associated idiopathic pulmonary fibrosis [31]. Furthermore, downregulation of Adrm1 at the mRNA and protein levels leads to slower wound-healing [32]. Insulin-like growth factor binding protein 7 (Igfbp7), a cell cycle arrest biomarker, is released in the earliest stages of acute kidney injury, which has been suggested to be an important predictor of acute kidney injury following cardiac surgery [33-35]. We hypothesize that Ckm, Adrm1 and Igfbp7 may also be involved in the early repair of lung injury by zinc chloride smoke inhalation.

Myosin light polypeptide 3 (Myl3) is a biomarker for monitoring muscle injury and recovery [26]. It has been found that Myl3 is significantly downregulated in spinal cord injuries [36]. In addition, it is a causal gene for hypertrophic cardiomyopathy [37]. It has been demonstrated that Myl3 is a plasma marker of cardiac injury [38]. In this study, we found that Myl3 was differentially expressed in the early stages of lung injury after smoke inhalation. It has been found that cardiac dysfunction results from the inhalational of $\mathrm{Cl}_{2}$; this exposure may result in pulmonary hypertension due to severe lung injury [39]. In addition, cardiac output varies in patients with acute lung injury with or without right ventricular dilatation [40]. We speculate that Myl3 may be involved in lung injury repair in the early stage after smoke inhalation.
Based on the KEGG enrichment analysis, the proteasome, protein processing in endoplasmic reticulum, the lysosome and glycolysis/gluconeogenesis were enriched signalling pathways and organelles. Aldehyde dehydrogenase 7A1 (ALDH7A1), Enolase 3 (Eno3) and triosephosphate isomerase 1 (Tpi1) were enriched in the glycolysis/gluconeogenesis signalling pathways. ALDH7A1 is a member of the ALDH superfamily. The primary function of these enzymes is the detoxification of endobiotic and xenobiotic aldehyde compounds into their corresponding weak carboxylic acids. Giacalone et al. reported that ALDH7A1 is the potential target of ALDH enzymes in the treatment of lung cancer [41]. Eno3 is a highly expressed protein in the lungs [42]. In guinea pig lungs, Eno3 is involved in glycolysis/gluconeogenesis [43]. It has been reported that Eno3 is upregulated in traumatic brain injury [44]. The expression of triosephosphate isomerase 1 (Tpi1) is low in smoking-induced emphysema lung models [45]. It is worth mentioning that Tpi1 is involved in the glycolysis or gluconeogenesis pathway in acute lung injury [46]. The lungs depend on circulation for glucose acquisition. Therefore, the glycolysis/gluconeogenesis signalling pathway is important in the physiological activities of the lungs. Our results suggest that ALDH7A1, Eno3 and Tpi1 may be involved in glucose metabolism in the middle-late stage of lung injury repair. 


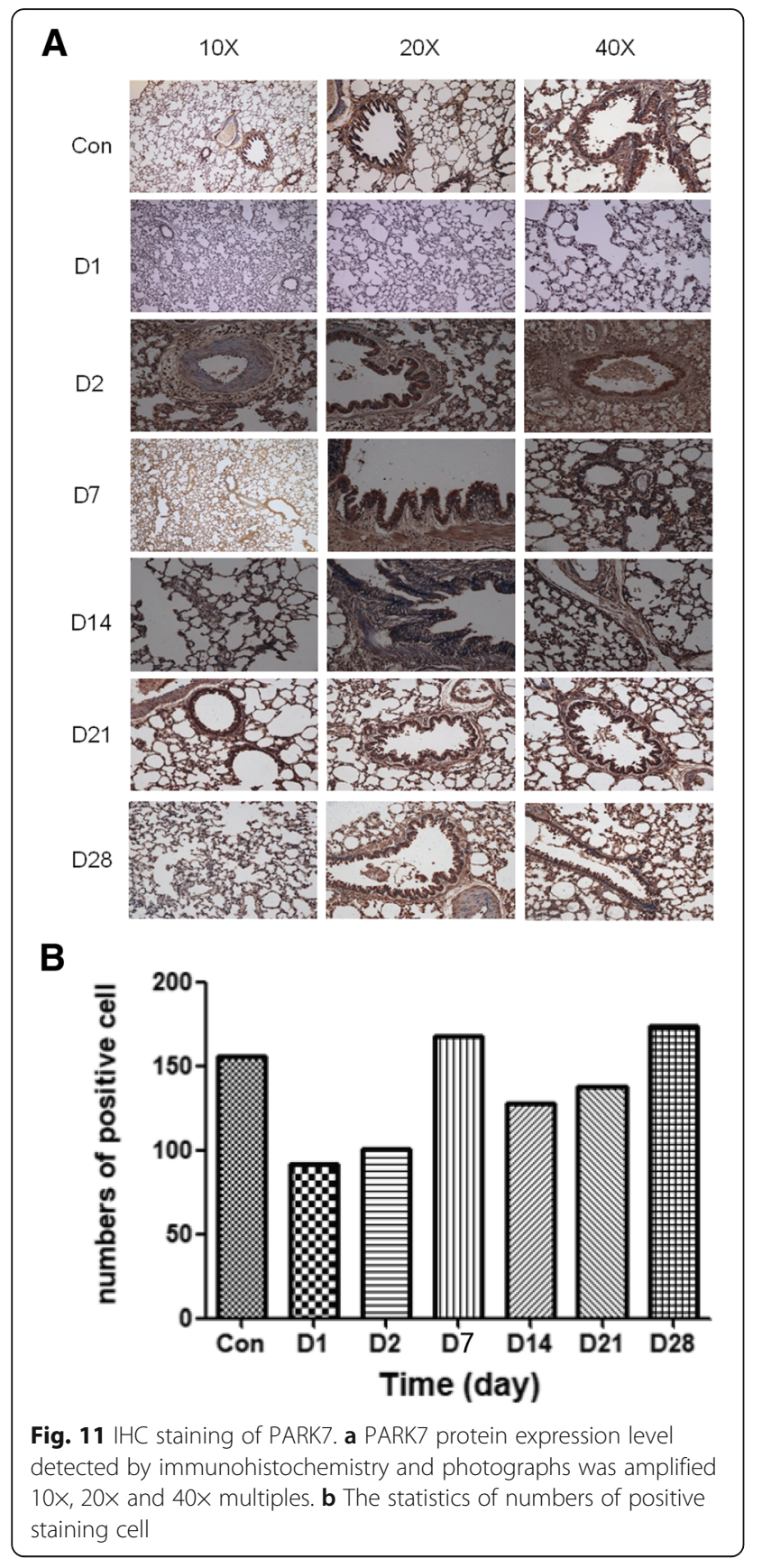

According to the PPI, we found highly expressed proteins, including Gapdh, Acly, Tnni2, Acta1, Actn3, Pygm, Eno3 and Tpi1. It is noted that all these proteins were differentially expressed in the middle-late stage of injury after smoke inhalation. It has been shown that glyceraldehyde-3-phosphate dehydrogenase (Gapdh) has an anti-inflammatory function in the lipopolysaccharide-induced severe acute lung injury mouse model [47]. ATP citrate lyase (Acly), a lipid biosynthesis transcript, plays an important role in chronic obstructive pulmonary disease [48]. It has been pointed out that Acly is downregulated in acrolein-induced acute lung injury [49]. Troponin I, skeletal fast 2 (Tnni2) plays a crucial role in lung veins [50]. In rats, Tnni2 is involved in angiogenesis in the early stage of skin incision wounds [51]. Actin, alpha 1 skeletal muscle (Acta1) is a representative marker of myocardial adaptive response to damage [52]. Significantly, Acta1 is a differentially regulated gene in nickel-induced acute lung injury [53]. Muscle glycogen phosphorylase (Pygm) is involved in glycogen metabolism [54]. The homozygous mutation in the Pygm gene leads to glycogen metabolism disorder in patients with acute kidney injury [55].

Parkinson's disease 7 (Park7) is autosomal recessive with an early onset and is a metabolic enzyme. The expression of Park7 is downregulated in lung development [56]. It has been found that Park7 is downregulated in asbestos-exposed epithelial and mesothelial lung cell lines [57]. In this study, we found that Park7 was upregulated on day 14 after zinc chloride smoke inhalation. In addition, the immunohistochemistry results showed that the expression of PARK7 was highest in the control group and decreased with time after zinc chloride smoke inhalation.

In addition to the proteins listed above, we also found some differentially expressed proteins (such as Lta4h and Fabp5) in the middle-late stages of injury after zinc chloride smoke inhalation. It is noted that Lta4h is a hub protein in the turquoise module of WGCNA analysis (Table 4). Leukotriene A4 hydrolase (Lta4h) polymorphisms are associated with baseline lung function [58]. It has been found that Lta4h is related to chronic obstructive pulmonary disease [59]. The epidermal fatty acid binding protein 5 (Fabp5) is expressed in lung tissues, especially in alveolar macrophages [60]. A previous study indicated that Fabp5 was downregulated in the airway epithelial cells of smokers with chronic obstructive pulmonary disease [61]. In addition, a microarray experiment showed the expression of Fabp5 in a mouse lung during nickel-induced lung injury [62]. Our WB results showed that the expression of FABP5 was the highest on day 14, which was consistent with the proteomics analysis. In addition, 10 differentially expressed proteins, including Gapdh, Acly, Tnni2, Acta1, Actn3, Pygm, Eno3, Tpi1, Lta4h, Fabp5 and the glycolysis/ gluconeogenesis signalling pathway, may play roles in the middle-late stage of zinc chloride smoke inhalation lung injury repair. However, there are limitations to our study. The biological functions of the identified differentially expressed proteins were not thoroughly investigated. Some in vivo or in vitro experiments, such as cell experiments, are needed. 

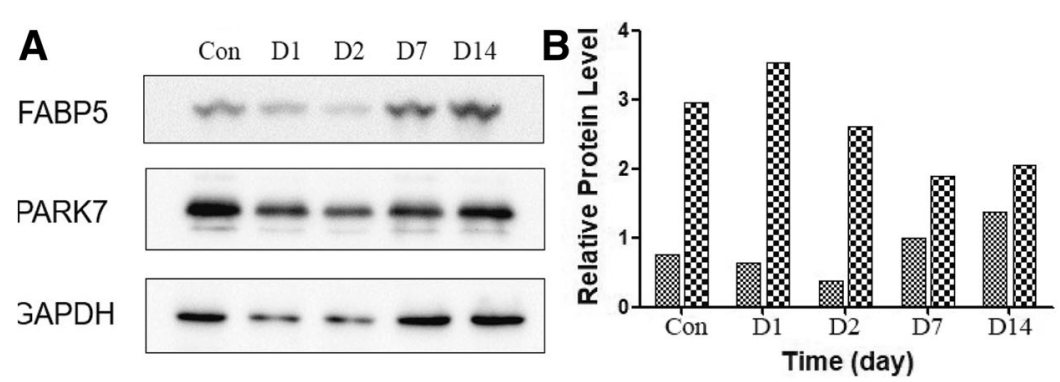

Fig. 12 Densitometric analysis of PARK7 and FABP5 protein expression after normalization to GAPDH. a PARK7 and FABP5 protein expression level detected by western blot. $\mathbf{b}$ The statistics analysis of protein band. Student t-test was used and all data were reported as mean \pm SD

\section{Conclusion}

We first analysed differentially expressed proteins on days $1,2,7$ and 14 after zinc chloride smoke inhalation in rats. Then, we further identified lung injury repair-related differentially expressed proteins in the early and middle-late stages of lung injury. The identified key proteins and related signalling pathways may play crucial roles in smoke inhalation lung injury repair.

\section{Abbreviations}

FDR: False discovery rate; GO: Gene Ontology; H\&E: Ematoxylin and eosin; IHC: Immunohistochemistry; Itraq: Isobaric tags for relative and absolute quantization; KEGG: Kyoto Encyclopedia of Genes and Genomes; PPI: Proteinprotein interaction; WB: Western blot; WGCNA: Weighted gene co-expression network analysis

\section{Acknowledgements}

None.

\section{Funding}

None.

\section{Availability of data and materials}

The dataset supporting the conclusions of this article is included within the article.

\section{Authors' contributions}

$X X, J Z, H W, Y X, Y S$ and $L M$ analyzed and interpreted the data. XX and JZ were major contributors in writing the manuscript. LX designed the project. All authors read and approved the final manuscript.

\section{Ethics approval and consent to participate}

This study was approved by the ethical committee of Chinese PLA General Hospital.

\section{Consent for publication}

Not applicable.

\section{Competing interests}

The authors declare that they have no competing interests.

\section{Publisher's Note}

Springer Nature remains neutral with regard to jurisdictional claims in published maps and institutional affiliations.

\section{Author details}

${ }^{1}$ Medical School of Chinese PLA, Medical School of Chinese PLA, Fuxing Road, Beijing 100853, China. ${ }^{2}$ Department of Respiratory, The Fourth Medical Center of Chinese PLA General Hospital, Beijing, China. ${ }^{3}$ Department of Pulmonary and Critical Care Medicine, Chinese PLA General Hospital, Beijing, China.
Received: 26 August 2018 Accepted: 4 February 2019

Published online: 15 February 2019

\section{References}

1. Zhang F, Li MY, Lan YT, Wang CB. Imbalance of Th17/Tregs in rats with smoke inhalation-induced acute lung injury. Sci Rep. 2016;6:21348.

2. Xie $F$, Zhang $X$, Xie L. Prognostic value of serum zinc levels in patients with acute $\mathrm{HC}$ /zinc chloride smoke inhalation. Medicine (Baltimore). 2017;96:e8156.

3. Cao L, Zhang XG, Wang JG, Wang HB, Chen YB, Zhao DH, Shi WF, Xie LX. Pulmonary function test findings in patients with acute inhalation injury caused by smoke bombs. J Thorac Dis. 2016;8:3160-7.

4. El Idrissi A, van Berkel $L$, Bonekamp NE, Dalemans DJ, van der Heyden MA. The toxicology of zinc chloride smoke producing bombs and screens. Clin Toxicol (Phila). 2017;55:167-74.

5. Rehberg S, Maybauer MO, Enkhbaatar P, Maybauer DM, Yamamoto Y, Traber DL. Pathophysiology, management and treatment of smoke inhalation injury. Expert Rev Respir Med. 2009;3:283-97.

6. Shirani $K Z$, Pruitt BA Jr, Mason AD Jr. The influence of inhalation injury and pneumonia on burn mortality. Ann Surg. 1987;205:82-7.

7. Suzuki M, Aikawa N, Kobayashi K, Higuchi R. Prognostic implications of inhalation injury in burn patients in Tokyo. Burns. 2005;31:331-6.

8. Zhu F, Qiu X, Wang J, Jin Y, Sun Y, Lv T, Xia Z. A rat model of smoke inhalation injury. Inhal Toxicol. 2012;24:356-64.

9. Ong SE, Mann M. Mass spectrometry-based proteomics turns quantitative. Nat Chem Biol. 2005;1:252-62.

10. Liu X, Wang J, Gao L, Liu H, Liu C. iTRAQ-based proteomic analysis of neonatal kidney from offspring of protein restricted rats reveals abnormalities in Intraflagellar transport proteins. Cell Physiol Biochem. 2017:44:185-99.

11. Li Y, Wang X, Ao M, Gabrielson E, Askin F, Zhang H, Li QK. Aberrant Mucin5B expression in lung adenocarcinomas detected by iTRAQ labeling quantitative proteomics and immunohistochemistry. Clin Proteomics. 2013;10:15.

12. Wisniewski JR, Zougman A, Nagaraj N, Mann M. Universal sample preparation method for proteome analysis. Nat Methods. 2009;6:359-62

13. Guo Z, Liu X, Li M, Shao C, Tao J, Sun W. Differential urinary glycoproteome analysis of type 2 diabetic nephropathy using 2D-LC-MS/MS and iTRAQ quantification. J Transl Med. 2015;13:371.

14. Alaei S, Sadeghi B, Najafi A, Masoudi-Nejad A. LncRNA and mRNA integration network reconstruction reveals novel key regulators in esophageal squamous-cell carcinoma. Genomics. 2018;111:76-89.

15. Chen PF, Wang F, Nie JY, Feng JR, Liu J, Zhou R, Wang HL, Zhao Q. Co-expression network analysis identified $\mathrm{CDH} 11$ in association with progression and prognosis in gastric cancer. Onco Targets Ther. 2018;11:6425-36.

16. Langfelder $P$, Horvath S. WGCNA: an R package for weighted correlation network analysis. BMC Bioinformatics. 2008;9:559.

17. Liu S, Xie F, Xiang X, Dong S, Qu K, Lin T. Identification of differentially expressed genes, IncRNAs and miRNAs which are associated with tumor malignant phenotypes in hepatoblastoma patients. Oncotarget. 2017:8:97554-64. 
18. Shannon P, Markiel A, Ozier O, Baliga NS, Wang JT, Ramage D, Amin N, Schwikowski B, Ideker T. Cytoscape: a software environment for integrated models of biomolecular interaction networks. Genome Res. 2003;13:2498-504

19. Zhai K, Kong X, Liu B, Lou J. Bioinformatics analysis of gene expression profiling for identification of potential key genes among ischemic stroke. Medicine (Baltimore). 2017;96:e7564.

20. Hsu HH, Tzao C, Chang WC, Wu CP, Tung HJ, Chen CY, Perng WC. Zinc chloride (smoke bomb) inhalation lung injury: clinical presentations, highresolution $C T$ findings, and pulmonary function test results. Chest. 2005;127:2064-71.

21. Greenfield RA, Brown BR, Hutchins JB, landolo JJ, Jackson R, Slater LN, Bronze MS. Microbiological, biological, and chemical weapons of warfare and terrorism. Am J Med Sci. 2002;323:326-40.

22. Homma S, Jones R, Qvist J, Zapol WM, Reid L. Pulmonary vascular lesions in the adult respiratory distress syndrome caused by inhalation of zinc chloride smoke: a morphometric study. Hum Pathol. 1992;23:45-50.

23. Ye Z, Liu X, Yang Y, Zhang X, Yu T, Li S, Feng Y, Luo G. The differential expression of novel circular RNAs in an acute lung injury rat model caused by smoke inhalation. J Physiol Biochem. 2018;74:25-33.

24. Lange M, Hamahata A, Enkhbaatar P, Esechie A, Connelly R, Nakano Y, Jonkam C, Cox RA, Traber LD, Herndon DN, Traber DL. Assessment of vascular permeability in an ovine model of acute lung injury and pneumonia-induced Pseudomonas aeruginosa sepsis. Crit Care Med. 2008:36:1284-9.

25. Fu ZH, Guo GH, Xiong ZF, Liao X, Liu MZ, Luo J. Early anticoagulation therapy for severe burns complicated by inhalation injury in a rabbit model. Mol Med Rep. 2017;16:7375-81.

26. Vlasakova K, Lane P, Michna L, Muniappa N, Sistare FD, Glaab WE. Response of novel skeletal muscle biomarkers in dogs to drug-induced skeletal muscle injury or sustained endurance exercise. Toxicol Sci. 2017; 156:422-7.

27. Lamerant N, Kieda C. Adhesion properties of adhesion-regulating molecule 1 protein on endothelial cells. FEBS J. 2005;272:1833-44.

28. Cherix N, Froquet R, Charette SJ, Blanc C, Letourneur F, Cosson P. A Phg2Adrm1 pathway participates in the nutrient-controlled developmental response in Dictyostelium. Mol Biol Cell. 2006;17:4982-7.

29. Hamazaki J, lemura S, Natsume T, Yashiroda H, Tanaka K, Murata S. A novel proteasome interacting protein recruits the deubiquitinating enzyme UCH37 to 265 proteasomes. EMBO J. 2006;25:4524-36.

30. Qiu XB, Ouyang SY, Li CJ, Miao S, Wang L, Goldberg AL. hRpn13/ADRM1/ GP110 is a novel proteasome subunit that binds the deubiquitinating enzyme, UCH37. EMBO J. 2006;25:5742-53.

31. Hao X, Du Y, Qian L, Li D, Liu X. Upregulation of long noncoding RNA AP003419.16 predicts high risk of agingassociated idiopathic pulmonary fibrosis. Mol Med Rep. 2017;16:8085-91.

32. Fejzo MS, Anderson L, von Euw EM, Kalous O, Avliyakulov NK, Haykinson MJ, Konecny GE, Finn RS, Slamon DJ. Amplification target ADRM1: role as an oncogene and therapeutic target for ovarian Cancer. Int J Mol Sci. 2013;14:3094-109.

33. Kashani K, Al-Khafaji A, Ardiles T, Artigas A, Bagshaw SM, Bell M, Bihorac A, Birkhahn R, Cely CM, Chawla LS, et al. Discovery and validation of cell cycle arrest biomarkers in human acute kidney injury. Crit Care. 2013;17:R25.

34. Kellum JA, Chawla LS. Cell-cycle arrest and acute kidney injury: the light and the dark sides. Nephrol Dial Transplant. 2016;31:16-22.

35. Wang Y, Zou Z, Jin J, Teng J, Xu J, Shen B, Jiang W, Zhuang Y, Liu L, Luo Z, et al. Urinary TIMP-2 and IGFBP7 for the prediction of acute kidney injury following cardiac surgery. BMC Nephrol. 2017;18:177.

36. Liu Y, Wang Y, Teng Z, Zhang X, Ding M, Zhang Z, Chen J, Xu Y. DNA microarray analysis in screening features of genes involved in spinal cord injury. Med Sci Monit. 2016;22:1571-81.

37. Marian AJ, Salek L, Lutucuta S. Molecular genetics and pathogenesis of hypertrophic cardiomyopathy. Minerva Med. 2001;92:435-51.

38. Thoonen R, Ernande L, Cheng J, Nagasaka Y, Yao V, Miranda-Bezerra A, Chen C, Chao W, Panagia M, Sosnovik DE, et al. Functional brown adipose tissue limits cardiomyocyte injury and adverse remodeling in catecholamine-induced cardiomyopathy. J Mol Cell Cardiol. 2015;84:202-11.

39. Zaky A, Bradley WE, Lazrak A, Zafar I, Doran S, Ahmad A, White CW, Dell'Italia LJ, Matalon S, Ahmad S. Chlorine inhalation-induced myocardial depression and failure. Physiol Rep. 2015;3:e12439.
40. Cepkova M, Kapur V, Ren X, Quinn T, Zhuo H, Foster E, Matthay MA, Liu KD. Clinical significance of elevated B-type natriuretic peptide in patients with acute lung injury with or without right ventricular dilatation: an observational cohort study. Ann Intensive Care. 2011;1:18.

41. Giacalone NJ, Den RB, Eisenberg R, Chen H, Olson SJ, Massion PP, Carbone DP, LU B. ALDH7A1 expression is associated with recurrence in patients with surgically resected non-small-cell lung carcinoma. Future Oncol. 2013;9:737-45.

42. Wu J, Zhou D, Deng C, Wu X, Long L, Xiong Y. Characterization of porcine ENO3: genomic and CDNA structure, polymorphism and expression. Genet Sel Evol. 2008;40:563-79.

43. Jain R, Dey B, Tyagi AK. Development of the first oligonucleotide microarray for global gene expression profiling in Guinea pigs: defining the transcription signature of infectious diseases. BMC Genomics. 2012;13:520.

44. Wu P, Zhao Y, Haidacher SJ, Wang E, Parsley MO, Gao J, Sadygov RG, Starkey JM, Luxon BA, Spratt $H$, et al. Detection of structural and metabolic changes in traumatically injured hippocampus by quantitative differential proteomics. J Neurotrauma. 2013;30:775-88.

45. Uh ST, Koo SM, Jang AS, Park SW, Choi JS, Kim YH, Park CS. Proteomic differences with and without ozone-exposure in a smoking-induced emphysema lung model. Korean J Intern Med. 2015;30:62-72.

46. Li Y, Jin S, Lei L, Pan Z, Zou X. Deciphering deterioration mechanisms of complex diseases based on the construction of dynamic networks and systems analysis. Sci Rep. 2015;5:9283.

47. Takaoka Y, Goto S, Nakano T, Tseng HP, Yang SM, Kawamoto S, Ono K, Chen CL. Glyceraldehyde-3-phosphate dehydrogenase (GAPDH) prevents lipopolysaccharide (LPS)-induced, sepsis-related severe acute lung injury in mice. Sci Rep. 2014;4:5204.

48. Li J, Zhao P, Yang L, Li Y, Tian Y, Li S, Bai Y. Integrating 3-omics data analyze rat lung tissue of COPD states and medical intervention by delineation of molecular and pathway alterations. Biosci Rep. 2017;37:BSR20170042.

49. Fabisiak JP, Medvedovic M, Alexander DC, McDunn JE, Concel VJ, Bein K, Jang AS, Berndt A, Vuga LJ, Brant KA, et al. Integrative metabolome and transcriptome profiling reveals discordant energetic stress between mouse strains with differential sensitivity to acrolein-induced acute lung injury. Mol Nutr Food Res. 2011;55:1423-34.

50. Millino C, Sarinella F, Tiveron C, Villa A, Sartore S, Ausoni S. Cardiac and smooth muscle cell contribution to the formation of the murine pulmonary veins. Dev Dyn. 2000;218:414-25.

51. Kameyama H, Udagawa O, Hoshi T, Toukairin Y, Arai T, Nogami M. The mRNA expressions and immunohistochemistry of factors involved in angiogenesis and lymphangiogenesis in the early stage of rat skin incision wounds. Leg Med (Tokyo). 2015;17:255-60.

52. Aztatzi-Aguilar OG, Uribe-Ramirez M, Arias-Montano JA, Barbier O, De Vizcaya-Ruiz A. Acute and subchronic exposure to air particulate matter induces expression of angiotensin and bradykinin-related genes in the lungs and heart: angiotensin-II type-I receptor as a molecular target of particulate matter exposure. Part Fibre Toxicol. 2015;12:17.

53. Mallakin A, Kutcher LW, McDowell SA, Kong S, Schuster R, Lentsch AB, Aronow BJ, Leikauf GD, Waltz SE. Gene expression profiles of Mst1r-deficient mice during nickel-induced acute lung injury. Am J Respir Cell Mol Biol. 2006;34:15-27.

54. Yavari A, Bellahcene M, Bucchi A, Sirenko S, Pinter K, Herring N, Jung JJ, Tarasov KV, Sharpe EJ, Wolfien M, et al. Mammalian gamma2 AMPK regulates intrinsic heart rate. Nat Commun. 2017:8:1258.

55. Zhao X, Li A, Soni M, Muriello MJ, Jones CH, Whittier WL. McArdle disease: a "pediatric" disorder presenting in an adult with acute kidney injury. CEN Case Rep. 2017;6:156-60

56. Chen L, Wilson R, Bennett E, Zosky GR. Identification of vitamin D sensitive pathways during lung development. Respir Res. 2016;17:47.

57. Nymark P, Lindholm PM, Korpela MV, Lahti L, Ruosaari S, Kaski S, Hollmen J, Anttila S, Kinnula VL, Knuutila S. Gene expression profiles in asbestos-exposed epithelial and mesothelial lung cell lines. BMC Genomics. 2007;8:62

58. Via M, De Giacomo A, Corvol H, Eng C, Seibold MA, Gillett C, Galanter J, Sen S, Tcheurekdjian $\mathrm{H}$, Chapela $\mathrm{R}$, et al. The role of LTA4H and ALOX5AP genes in the risk for asthma in Latinos. Clin Exp Allergy. 2010;40:582-9.

59. Tulah AS, Parker SG, Moffatt MF, Wardlaw AJ, Connolly MJ, Sayers I. The role of ALOX5AP, LTA4H and LTB4R polymorphisms in determining baseline lung function and COPD susceptibility in UK smokers. BMC Med Genet. 2011;12:173. 
60. Ghelfi E, Karaaslan C, Berkelhamer S, Akar S, Kozakewich H, Cataltepe S. Fatty acid-binding proteins and peribronchial angiogenesis in bronchopulmonary dysplasia. Am J Respir Cell Mol Biol. 2011;45:550-6.

61. Gally F, Chu HW, Bowler RP. Cigarette smoke decreases airway epithelial FABP5 expression and promotes Pseudomonas aeruginosa infection. PLoS One. 2013;8:e51784.

62. Bein K, Wesselkamper SC, Liu X, Dietsch M, Majumder N, Concel VJ, Medvedovic M, Sartor MA, Henning LN, Venditto C, et al. Surfactantassociated protein $B$ is critical to survival in nickel-induced injury in mice. Am J Respir Cell Mol Biol. 2009;41:226-36.

Ready to submit your research? Choose BMC and benefit from:

- fast, convenient online submission

- thorough peer review by experienced researchers in your field

- rapid publication on acceptance

- support for research data, including large and complex data types

- gold Open Access which fosters wider collaboration and increased citations

- maximum visibility for your research: over $100 \mathrm{M}$ website views per year

At BMC, research is always in progress.

Learn more biomedcentral.com/submissions 